\title{
Stratigraphic Variations of Fe-Mn Micronodules and Implications for the Formation of Extremely REY-Rich Mud in the Western North Pacific Ocean
}

\author{
Kazutaka Yasukawa ${ }^{1,2,3} \mathbb{D}^{D}$, Satoshi Kino ${ }^{2}$, Junichiro Ohta ${ }^{1,2,3}$, Keishiro Azami ${ }^{2}$, Erika Tanaka ${ }^{2}$, \\ Kazuhide Mimura ${ }^{2}$, Koichiro Fujinaga ${ }^{1,3}$, Kentaro Nakamura ${ }^{2}$ and Yasuhiro Kato 1,2,3,4,*
}

Citation: Yasukawa, K.; Kino, S.; Ohta, J.; Azami, K.; Tanaka, E.; Mimura, K.; Fujinaga, K.; Nakamura, K.; Kato, Y. Stratigraphic Variations of $\mathrm{Fe}-\mathrm{Mn}$ Micronodules and Implications for the Formation of Extremely REY-Rich Mud in the Western North Pacific Ocean. Minerals 2021, 11, 270. https:// doi.org/10.3390/ $\min 11030270$

Academic Editors: Francisco J. González and Georgy Cherkashov

Received: 14 January 2021

Accepted: 3 March 2021

Published: 6 March 2021

Publisher's Note: MDPI stays neutral with regard to jurisdictional claims in published maps and institutional affiliations.

Copyright: (C) 2021 by the authors Licensee MDPI, Basel, Switzerland This article is an open access article distributed under the terms and conditions of the Creative Commons Attribution (CC BY) license (https:// creativecommons.org/licenses/by/ $4.0 /)$
1 Frontier Research Center for Energy and Resources, School of Engineering, The University of Tokyo, Bunkyo-ku, Tokyo 113-8656, Japan; k-yasukawa@sys.t.u-tokyo.ac.jp (K.Y.); junichiro.ota@sys.t.u-tokyo.ac.jp (J.O.); k-fujinaga@sys.t.u-tokyo.ac.jp (K.F.)

2 Department of Systems Innovation, School of Engineering, The University of Tokyo, Bunkyo-ku, Tokyo 113-8656, Japan; satoshi.familia38@gmail.com (S.K.); k.azami@egeo.t.u-tokyo.ac.jp (K.A.); erika.t@egeo.t.u-tokyo.ac.jp (E.T.); kaz-mimura@egeo.t.u-tokyo.ac.jp (K.M.); kentaron@sys.t.u-tokyo.ac.jp (K.N.)

3 Ocean Resources Research Center for Next Generation, Chiba Institute of Technology, Narashino 275-0016, Japan

4 Submarine Resources Research Center, Research Institute for Marine Resources Utilization, Japan Agency for Marine-Earth Science and Technology (JAMSTEC), Yokosuka 237-0061, Japan

* Correspondence: ykato@sys.t.u-tokyo.ac.jp; Tel.: +81-3-5841-7022

\begin{abstract}
The origin of deep-sea sediments in the western North Pacific Ocean, which are significantly enriched in rare-earth elements and yttrium (REY), and its paleoceanographic implications have been poorly constrained. Here, we investigated stratigraphic variations in the chemical compositions and textures of ferromanganese ( $\mathrm{Fe}-\mathrm{Mn}$ ) micronodules separated from western North Pacific sediments. The characteristics of the micronodules of an extremely REY-rich mud layer vary from almost purely diagenetic to relatively hydrogenetic. This indicates the abundant supply of organic matter to the sediment together with fish debris that accumulates REY at the onset of the REY-enrichment of the mud, followed by the exposure of the seafloor to oxic water masses during the latter half of the formation of the REY-rich mud. These results support a previously proposed formation mechanism based on which enhanced bottom water currents caused pelagic fish proliferation via the upwelling of nutrients and fish debris was physically sorted and selectively accumulated on the seafloor. After the main REY-enrichment, the micronodules exhibit varying diagenetic signatures, suggesting changes in the bottom current intensities after the main REY-enrichment. However, the bulk REY contents do not increase. This implies that a sufficient increase in the fish productivity is an essential factor affecting the formation of REY-rich mud.
\end{abstract}

Keywords: seafloor mineral resources; ferromanganese micronodule; REY-rich mud; deep-sea sediment; bottom water current; Pacific Ocean; Minamitorishima Island

\section{Introduction}

Ferromanganese (Fe-Mn) micronodules are ubiquitous constituents of oxic deep-sea sediments. They are submillimeter-sized particles that are mainly composed of Fe-Mn (oxyhydr)oxides and rich in multiple transition metals with significantly varying abundances, reflecting environmental factors such as redox conditions. Thus, they are expected to be effective indicators of the sedimentary environment in the pelagic realm [1-9].

Deep-sea sediments around Minamitorishima Island, that is, the easternmost island of Japan in the western North Pacific Ocean, exhibit a total rare-earth element and yttrium ( $\mathrm{REY}$ ) content of up to 8000 ppm [10-14]. To the best of our knowledge, this is the highest REY content reported for REY-rich mud among marine sediments worldwide (e.g., [15-26]). 
The main host of REY in deep-sea sediments is calcium phosphate (apatite), which is present in form of fish teeth and bone fragments (fish debris) in the sediments [12,27-33]. Because teeth and bones in living fish indicate REY contents several orders of magnitude lower than those in deep-sea sediments [29], previous studies concluded that fish debris incorporate REY from seawater after deposition on the seafloor and/or from pore water during early diagenesis after burial [28-30,33]. The average $\Sigma$ REY of fish debris in western North Pacific sediments is $>15,000 \mathrm{ppm}$ (maximum: 22,000 ppm) [12]. Therefore, the very high $\Sigma R E Y$ contents of the bulk sediments have been attributed to a significant accumulation of fish debris (up to 30 modal percent [34]). From a palaeoceanographic perspective, it is likely that such an anomalous concentration of REY, or fish debris, in deep-sea sediments reflects specific conditions of the pelagic environment.

Based on the multi-elemental chemostratigraphy of bulk sediments, Tanaka et al. [35] revealed at least three distinct layers that are significantly enriched in REY ( $\Sigma R E Y>2000 \mathrm{ppm})$ in the Minamitorishima area. Tanaka et al. [35] named these characteristic layers in the sediment column 1st, 2nd, and 3rd REY peaks, from shallow to deep. By using marine osmium isotopes and ichthyolith (i.e., fish teeth and denticles) stratigraphy, Ohta et al. [36] demonstrated that the 1st REY peak was formed 34.4 million years ago, concurrent with the temporal expansion of the Antarctic icesheet (called "Late Eocene event") preceding the Eocene-Oligocene climate transition (global cooling). Based on this synchronicity, Ohta et al. [36] proposed the following hypothesis regarding the genesis of the extremely REY-rich mud. The Late Eocene event induced the formation of bottom water around Antarctica and enhanced the northward inflow of bottom water in the North Pacific. The strengthened bottom current caused the upwelling of deep-ocean nutrients along with topographic highs, such as large seamounts, and stimulated the biological productivity in the surface ocean. These processes resulted in an increased fish productivity, leading to the substantial deposition of fish debris that accumulate REY on the seafloor. However, the sequence of the changes in the sedimentary environment remains unclear.

Yasukawa et al. [37] reported that Fe-Mn micronodules in the deep-sea sediments south of Minamitorishima Island, including the extremely REY-rich mud, have a diagenetic origin and contain up to 2900 ppm Co, 7200 ppm Cu, and 39,000 ppm Ni. Although the authors did not investigate these Fe-Mn micronodules from a paleoceanographic perspective, these geochemical features could be indicators of the environmental conditions during the formation of the extremely REY-rich mud. Hence, in this study, we focused on the downcore variations of the geochemical features of the Fe-Mn micronodules in the sediment column, including the extremely REY-rich mud. We first characterized the chemical compositions of the Fe-Mn micronodules using multivariate statistical analysis. We also focused on the morphology and surficial textures of the micronodules. Based on the combination of all results, we discuss possible changes in the sedimentary environment during and after the formation of the 1st REY peak in the Minamitorishima area as well as the implications for the environment/oceanography with respect to the formation of the extremely REY-rich mud.

\section{Materials and Methods}

\subsection{Samples and Data}

In this study, three piston cores were investigated, which were collected south of Minamitorishima Island in the western North Pacific Ocean during the MR14-E02 cruise operated by the Japan Agency for Marine-Earth Science and Technology and the University of Tokyo. The targeted cores MR14-E02 PC05, PC09, and PC11 (Figure 1) consist of pelagic brown clay with variable abundances of silt-sized zeolite (phillipsite) and apatite (fish debris) grains (Figure 2). The $\Sigma$ REY content and chemostratigraphic classification of the bulk sediment defined by Tanaka et al. [35] are shown in Figure 2. Considering that the REY-enriched layers in the studied cores are located between Units II and III, all bulk sediment REY peaks from which the Fe-Mn micronodules were separated correspond to the 1st REY peak [35]. 
Cores PC05 and PC09 contain extremely REY-rich mud ( $\Sigma$ REY > 5000 ppm; [10]) and exhibit prominent peaks with bulk $\Sigma$ REY contents reaching 6200 ppm $(3.28 \mathrm{~m}$ below the seafloor, mbsf) and 8000 ppm (4.81 mbsf), respectively. In contrast, PC11 is characterized by a broader peak with a bulk $\Sigma$ REY content reaching up to 4100 ppm (9.98 mbsf), which corresponds to highly REY-rich mud (defined as $\Sigma$ REY = 2000-5000 ppm; [10]).

Yasukawa et al. [37] handpicked Fe-Mn micronodules from 30 horizons of the three cores (11 horizons in PC05, 11 horizons in PC09, and eight horizons in PC11) and determined their chemical compositions using an inductively coupled plasma quadrupole mass spectrometer. Note that the analytical results represent the bulk chemical composition of multiple micronodules ( $\sim 5$ to $15 \mathrm{mg}$ of the micronodules per sampling horizon were used for acid digestion), not that of a single sample. All chemical composition data have been presented in Yasukawa et al. [37].

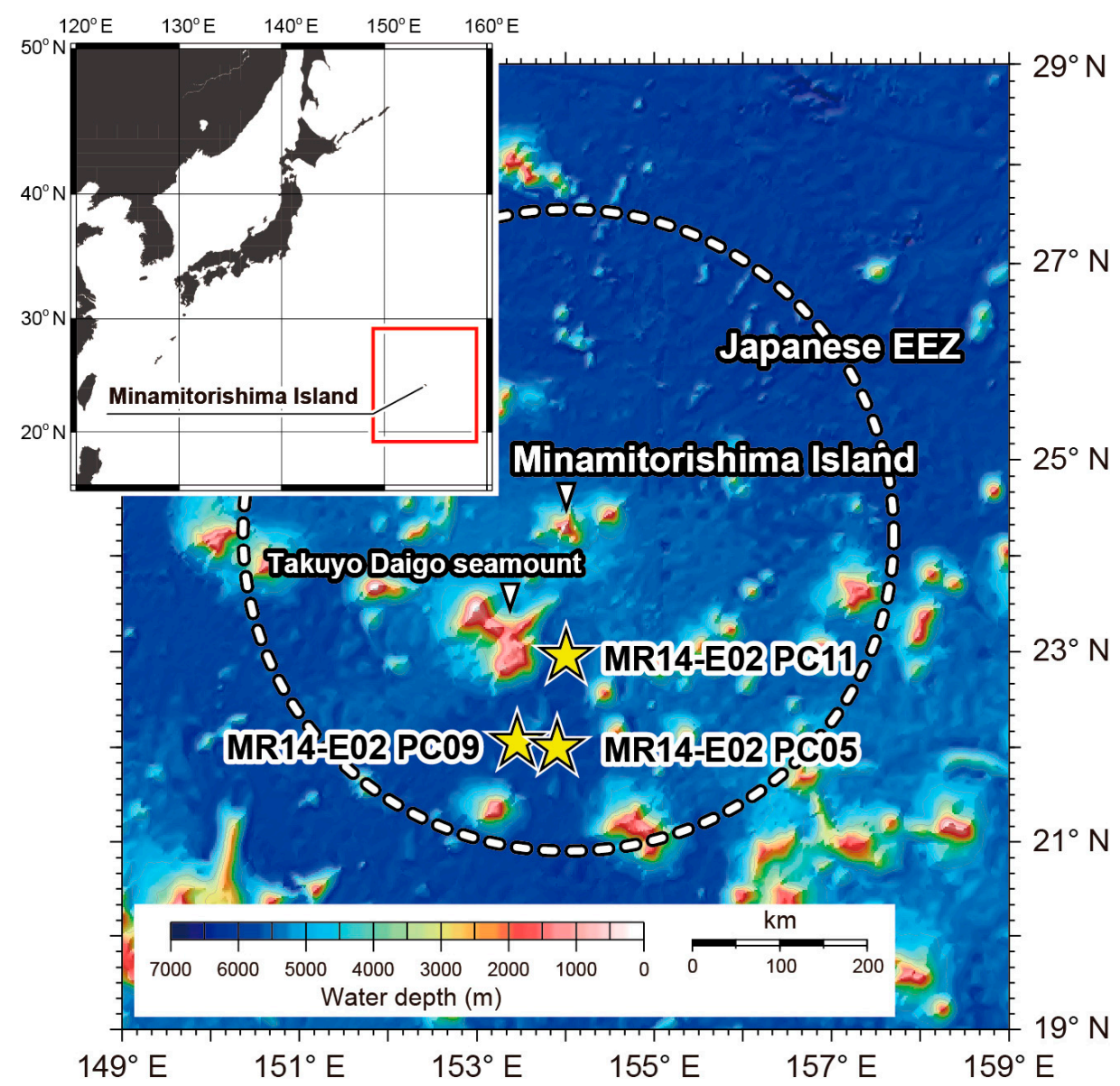

Figure 1. Locations of the study sites modified from [10] and [37]. 


\section{(a) MR14-E02 PC05}

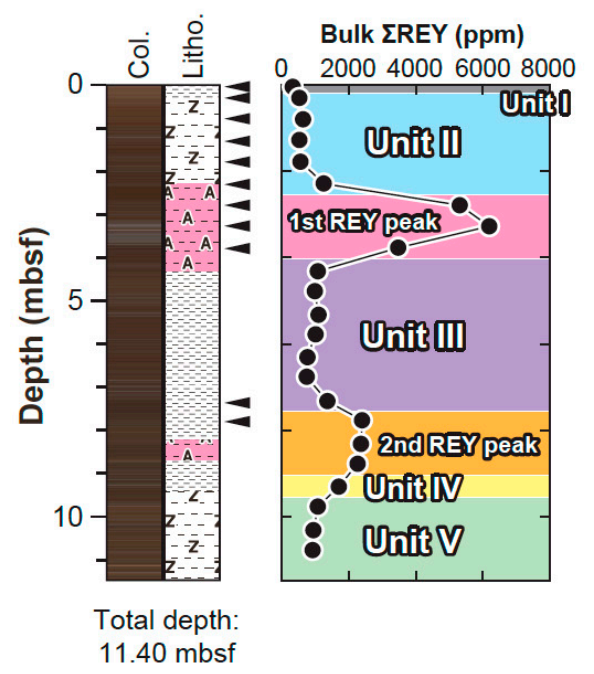

(b) MR14-E02 PC09

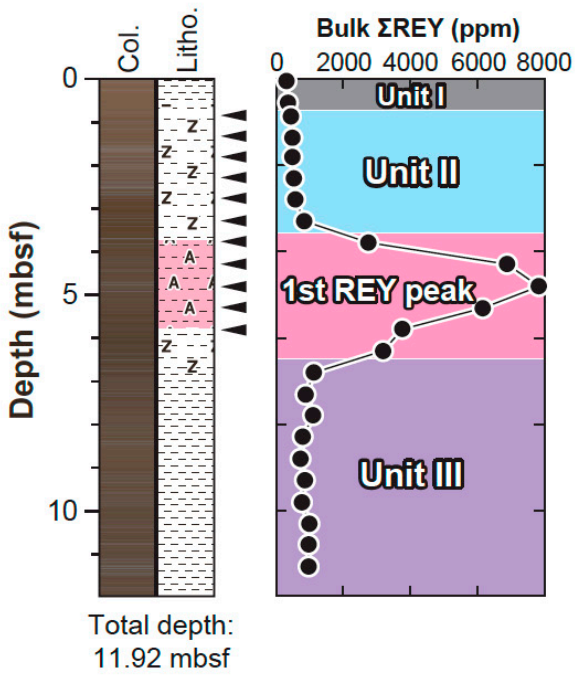

(c) MR14-E02 PC11

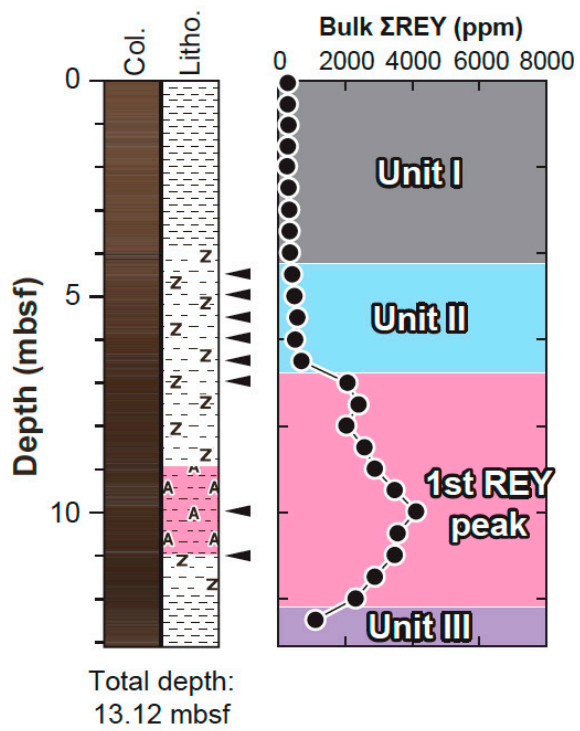

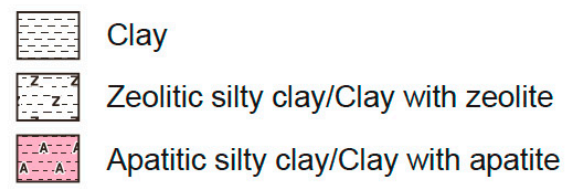

\section{Sampling horizon of} Fe-Mn micronodules

Figure 2. Lithostratigraphic and chemostratigraphic information about the studied cores. The sediment color, lithology, and chemostratigraphic units were obtained from [35]. The total rare-earth element and yttrium ( $\Sigma$ REY) contents in bulk sediments were taken from [13]. The black triangles indicate the horizons from which Fe-Mn micronodules were collected [37]. Col.: sediment color; Litho.: sediment lithology; mbsf: meters below seafloor.

\subsection{Statistical Classification}

In this study, we employed K-means cluster analysis (KCA) to classify the Fe-Mn micronodules based on their geochemical characteristics. The KCA is a widely used classification method based on which samples are partitioned into a set of $K$-clusters using multivariate data [38-42]. In this study, we used the $\mathrm{Fe}, \mathrm{Mn}, \mathrm{Co}, \mathrm{Ni}, \mathrm{Cu}$, and Mo contents as a set of variables because these elements are abundant in the Fe-Mn (oxyhydr)oxide phase of the micronodules and thus reflect the geochemical features of the micronodules [37]. Although the Fe-Mn (oxyhydr)oxides also contain Ce, we excluded Ce from the analysis because Yasukawa et al. [37] reported that the bulk Ce contents of several Fe-Mn micronodules from extremely/highly REY-rich mud layers are affected by fish debris in the micronodules. The effect of fish debris on the other six elements is minimal because of their low concentrations in fish debris [12].

First, the original data were centered according to the mean of each variable. Subsequently, they were uncorrelated using a principal component analysis (PCA) algorithm and scaled based on the standard deviations (i.e., square roots of the eigenvalues) along the principal components. This preprocessing, called "whitening," highlights the essential structure of the multivariate dataset $[14,39,40]$. In addition, a "dimensionality reduction" considering the eigenvalues was performed to exclude noise and stabilize the numerical process. Subsequently, we applied KCA to the whitened and dimensionality-reduced data to classify them based on their essential data structures [39]. The results of the KCA vary depending on the initial centroid values (i.e., mean of a cluster), which are generally pseudorandom numbers provided by a numerical program. Therefore, 100,000 KCA trials with different initial conditions were performed to optimize the clustering and minimize the total distance between the centroid and individual data points within each cluster [39]. The number of clusters, $K$, is an arbitrary parameter in KCA. Because there is no objective principle to determine $K$, we performed the analysis by varying $K$ and subsequently determined the final result based on comparison. 


\section{Results and Discussion}

\subsection{Downcore Geochemical Variations of the Fe-Mn Micronodules}

Figure 3 shows the downcore variations of the key elements of the Fe-Mn micronodules reported by Yasukawa et al. [37]. For comparison, the $\Sigma$ REY content of the bulk sediment from which the Fe-Mn micronodule samples were separated is also shown in Figure 3. The following characteristic trends or maxima were observed for the elemental contents depending on the core depth.
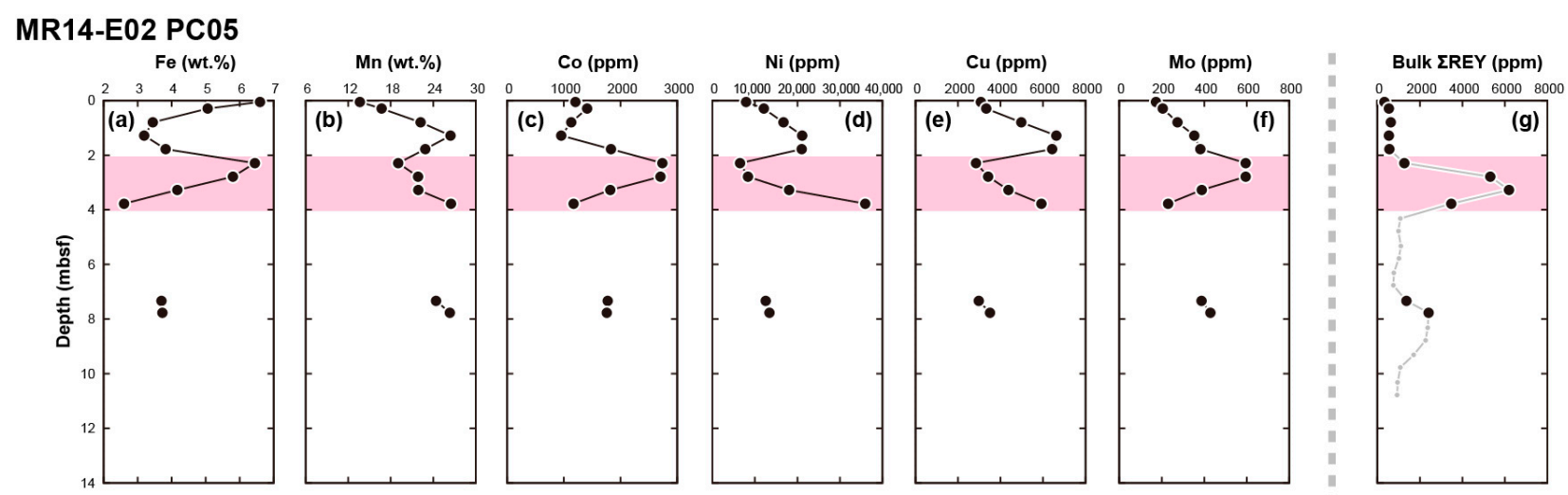

\section{MR14-E02 PC09}
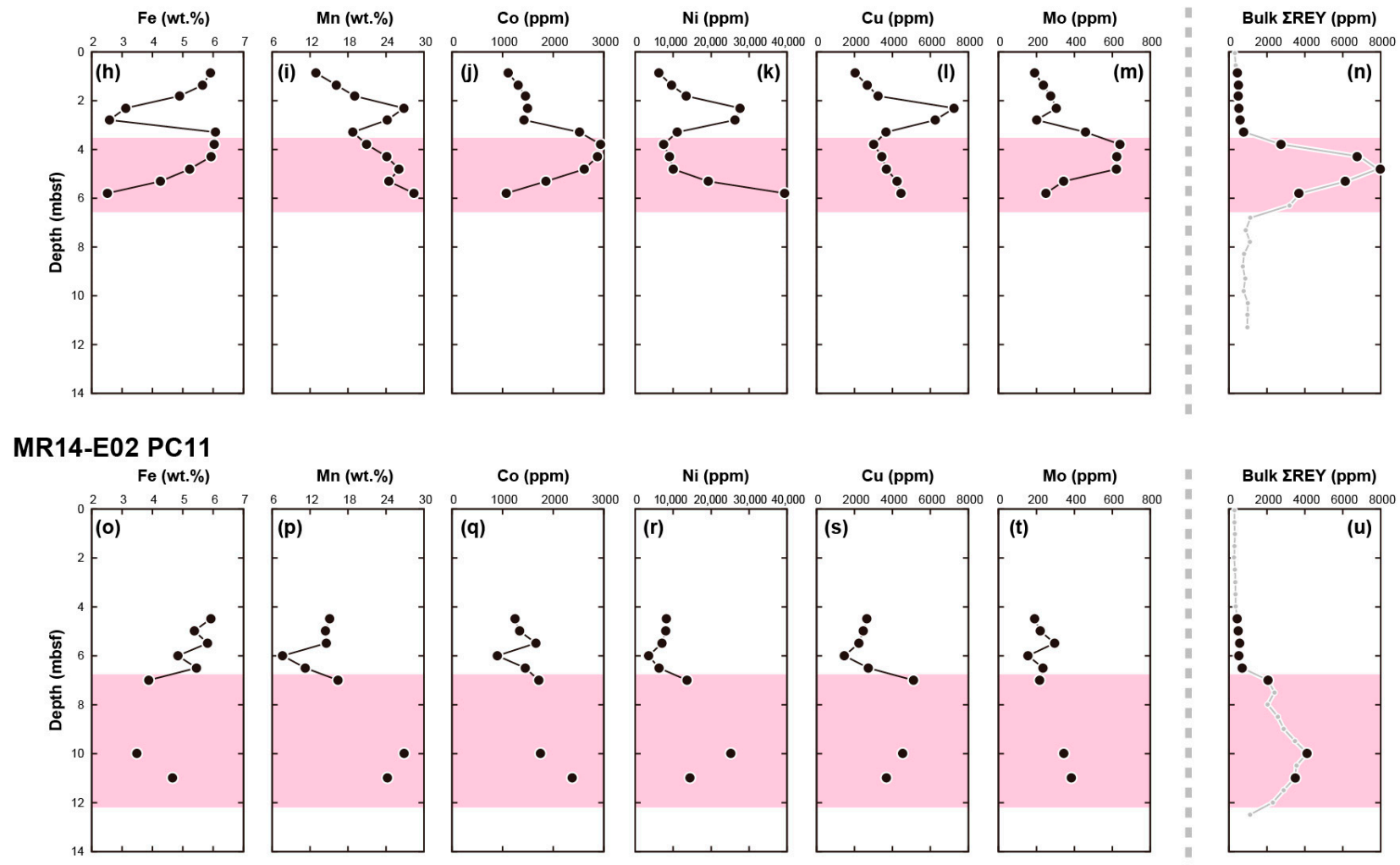

Figure 3. Downcore variations of the key element contents for each piston core. $(\mathbf{a}-\mathbf{f}, \mathbf{h}-\mathbf{m}, \mathbf{o}-\mathbf{t})$ Element contents of the Fe-Mn micronodules (data were obtained from [37]). (g,n,u) The $\Sigma$ REY contents of the bulk sediments are shown in gray [13]. Horizontal pink bars indicate the 1st REY peaks [35]. The black solid circles indicate the horizons from which the $\mathrm{Fe}-\mathrm{Mn}$ micronodules were collected.

The Fe content is relatively high in the top (0.05-0.30 mbsf in MR14-E02 PC05 and 0.86-1.86 mbsf in PC09) and middle (2.29-2.79 mbsf in PC05 and 3.29-4.81 mbsf in PC09) parts of the profiles (Figure 3a,h). The Fe content of the micronodules in the upper halves of the bulk sediment REY peak is increased. The Co and Mo contents also show prominent 
maxima in the middle of each profile in cores PC05 and PC09, corresponding to those of the Fe content (Figure $3 \mathrm{c}, \mathrm{f}, \mathrm{j}, \mathrm{m}$ ). However, in contrast to $\mathrm{Fe}$, neither the Co nor Mo contents in the micronodules in the uppermost parts of the profiles are high. Similar to Fe, it should be noted that the maxima of the Co and Mo contents of the micronodules were determined slightly above the maxima of the bulk sediment $\Sigma$ REY content in both PC05 and PC09. Compared with PC05 and PC09, general features are less notable in the element content profiles of PC11, which is partly due to the lack of a continuous profile of the micronodule composition because of the paucity of sand-sized micronodules [37].

The $\mathrm{Ni}$ and $\mathrm{Cu}$ contents of the micronodules between $0.80-1.78 \mathrm{mbsf}$ in PC05 and 2.31-2.79 mbsf in PC09 are high (Figure 3d,e,k,1). Furthermore, significantly higher Ni contents of up to 36,000-39,000 ppm were observed at 3.78 and $5.80 \mathrm{mbsf}$ in PC05 and PC09, respectively (Figure 3d,k). These maxima correspond to the lower halves of the bulk sediment REY peaks. The Mn content of the micronodules in these intervals is also high; it decreases toward the tops of the profiles (Figure $3 b, \mathrm{i}$ ).

\subsection{Results of the $K C A$}

Based on the results of the PCA (Table S1), three principal components account for $95.3 \%$ of the total sample variance (component $1: 54.6 \%$, component 2: $36.2 \%$, and component 3: $4.5 \%$ ). The fourth to sixth principal components only account for less than $2.4 \%$ of the variance. We regarded these signals, which might include noise or data uncertainty, to be unimportant. Thus, we reduced the dimensionality from the original six-element data to three-dimensional whitened data. Although there is no rule for the determination of the number of clusters $K$, Iwamori et al. [39] suggested $K=r$ to $3 r$ as a reasonable range to search for an appropriate $K$, where $r$ is the reduced data dimension. Therefore, we started searching for an appropriate number by using $K=3$ in the present analysis. One caveat is that the numbering of the clusters (e.g., cluster 1, cluster 2, etc.) in each calculation is random and does not indicate any priority or importance of clusters. Note also that the numbering of clusters for each result of the classification based on a different clustering parameter $K$ is independent.

The results obtained with $K=3$ are presented in Supplementary Figures S1 and S2. Note that the distribution of each cluster appears to be stratigraphically systematic rather than random when each sample horizon is labeled by the cluster (Supplementary Figure S1). The top- and lowermost samples in the sediment columns of all three cores were classified as cluster 1 (C1) and C2, respectively. In addition, C3 commonly occurs between $\mathrm{C} 1$ and C2 in PC09 and PC11. However, C2 and C3 alternate in PC05, leading to a somewhat ambiguous relationship between the clusters and geochemical features of the samples.

When $K$ is increased to four (Supplementary Figures S3 and S4), the stratigraphic distribution of each cluster becomes clearer compared with the use of $K=3$. In PC05 and $\mathrm{PC} 09$, the clusters of the Fe-Mn micronodules can be stratigraphically ordered from the seafloor to the depth as follows (Supplementary Figure S3): C4, C3, C1, and C2. This order is consistent with that observed in PC11, although the sample set from this core lacks C1.

When $K$ is further increased to five (Figures 4 and 5), the samples with the highest $\mathrm{Ni}$ contents ( $\mathrm{Ni}=36,000-39,000 \mathrm{ppm})$ in PC05 and PC09 are separated and constitute a new cluster. The other clusters remain unchanged. The stratigraphic order of the five clusters from the seafloor to the depth is as follows (Figure 4): C2, C3, C5, C1, and C4.

The results obtained with $K=6$ are presented in Supplementary Figures S5 and S6. In this case, the lowermost sample in PC09, which has the highest Ni content $(39,000$ ppm) of the entire dataset, constitutes a cluster (C1) by itself. In addition, the stratigraphic distributions of the other clusters are complex; for example, $\mathrm{C} 5$ occurs both above and beneath $\mathrm{C} 3$ around the maximum $\mathrm{Cu}$ content in PC05 and PC09. In PC05, the sample with the highest Ni content (36,000 ppm) is classified as C5 and intercalates with C4.

Considering that (1) sufficiently detailed classification is required to capture the geochemical features of each sample, (2) the consistency of the stratigraphic alignment of the clusters in different cores is geologically meaningful, and (3) clusters composed of only 
a single sample seem to be too detailed, we finally chose the results obtained with $K=5$ as the favorable results of our KCA (Table 1). In the remainder of the manuscript, we use five clusters to describe the Fe-Mn micronodules and sedimentary horizons from which they were collected.

Table 1. Element contents used for the cluster analysis, clustering results, and surface textures of the Fe-Mn micronodules.

\begin{tabular}{|c|c|c|c|c|c|c|c|c|c|c|}
\hline $\begin{array}{c}\text { Sample } \\
\text { (Core, Section, Interval) }\end{array}$ & $\begin{array}{l}\text { Depth } \\
\text { (mbsf) }\end{array}$ & $\underset{\text { (wt. \%) }}{\mathrm{Mn}}$ & $\underset{\text { (wt.\%) }}{\mathrm{Fe}}$ & $\begin{array}{l}\text { Co } \\
(\mathrm{ppm})\end{array}$ & $\begin{array}{c}\mathrm{Ni} \\
(\text { ppm) }\end{array}$ & $\begin{array}{l}\mathrm{Cu} \\
(\mathrm{ppm})\end{array}$ & $\begin{array}{l}\text { Mo } \\
(\mathrm{ppm})\end{array}$ & $\begin{array}{l}\text { Cluster } \\
(K=5)\end{array}$ & Texture of Micronodules & Note \\
\hline \multicolumn{11}{|c|}{ MR14-E02 PC05 } \\
\hline Sec. $1,4-6 \mathrm{~cm}$ & 0.05 & 13.6 & 6.60 & 1206 & 7955 & 3078 & 172 & 2 & $\mathrm{~B}$ & - \\
\hline Sec. $2,4-6 \mathrm{~cm}$ & 0.30 & 16.7 & 5.06 & 1408 & 12,082 & 3324 & 205 & 2 & $\mathrm{~B}$ & - \\
\hline Sec. $2,54-56 \mathrm{~cm}$ & 0.80 & 22.2 & 3.45 & 1132 & 16,684 & 4971 & 274 & 3 & $\mathrm{~B}$ & - \\
\hline Sec. $3,4-6 \mathrm{~cm}$ & 1.28 & 26.4 & 3.20 & 953 & 21,158 & 6620 & 353 & 3 & $\mathrm{~B}$ & - \\
\hline Sec. $3,54-56 \mathrm{~cm}$ & 1.78 & 22.9 & 3.82 & 1835 & 20,997 & 6435 & 381 & 3 & $\mathrm{~B}$ & - \\
\hline Sec. $4,4-6 \mathrm{~cm}$ & 2.29 & 19.1 & 6.44 & 2739 & 6545 & 2846 & 595 & 5 & $S$ and SL & Mixed. \\
\hline Sec. $4,54-56 \mathrm{~cm}$ & 2.79 & 21.9 & 5.80 & 2706 & 8357 & 3427 & 595 & 5 & S and SL & $\mathrm{S}$ is dominant. \\
\hline Sec. $5,4-6 \mathrm{~cm}$ & 3.28 & 21.9 & 4.17 & 1818 & 18,036 & 4371 & 388 & 1 & $\mathrm{~S}$ & - \\
\hline Sec. $5,54-56 \mathrm{~cm}$ & 3.78 & 26.5 & 2.60 & 1171 & 35,979 & 5932 & 229 & 4 & $\mathrm{~B}$ & - \\
\hline Sec. $9,10-12 \mathrm{~cm}$ & 7.33 & 24.4 & 3.70 & 1770 & 12,547 & 2982 & 387 & 1 & S and SL & $\mathrm{S}$ is dominant. \\
\hline Sec. $9,54-56 \mathrm{~cm}$ & 7.77 & 26.3 & 3.73 & 1754 & 13,425 & 3504 & 429 & 1 & $S$ and SL & $\mathrm{S}$ is dominant. \\
\hline \multicolumn{11}{|c|}{ MR14-E02 PC09 } \\
\hline Sec. $2,4-6 \mathrm{~cm}$ & 0.86 & 12.9 & 5.91 & 1110 & 6225 & 2027 & 190 & 2 & S & - \\
\hline Sec. $2,54-56 \mathrm{~cm}$ & 1.36 & 16.2 & 5.65 & 1309 & 9546 & 2676 & 236 & 2 & S & - \\
\hline Sec. $3,4-6 \mathrm{~cm}$ & 1.81 & 19.0 & 4.89 & 1449 & 13,430 & 3241 & 275 & 2 & $B$ and $S$ & Mixed. \\
\hline Sec. $3,54-56 \mathrm{~cm}$ & 2.31 & 26.8 & 3.12 & 1494 & 27,635 & 7247 & 305 & 3 & B & - \\
\hline Sec. $4,4-6 \mathrm{~cm}$ & 2.79 & 24.2 & 2.58 & 1424 & 26,270 & 6259 & 201 & 3 & B & - \\
\hline Sec. $4,54-56 \mathrm{~cm}$ & 3.29 & 18.8 & 6.07 & 2519 & 11,072 & 3666 & 459 & 5 & S & - \\
\hline Sec. $5,4-6 \mathrm{~cm}$ & 3.79 & 20.9 & 6.04 & 2937 & 7474 & 3014 & 640 & 5 & SL & - \\
\hline Sec. $5,54-56 \mathrm{~cm}$ & 4.29 & 24.1 & 5.93 & 2875 & 9022 & 3440 & 624 & 5 & SL & - \\
\hline Sec. $6,4-6 \mathrm{~cm}$ & 4.81 & 26.1 & 5.23 & 2617 & 10,000 & 3683 & 621 & 5 & SL & - \\
\hline Sec. $6,54-56 \mathrm{~cm}$ & 5.31 & 24.4 & 4.26 & 1856 & 19,225 & 4241 & 343 & 1 & $S$ & - \\
\hline Sec. $7,4-6 \mathrm{~cm}$ & 5.80 & 28.4 & 2.52 & 1076 & 39,338 & 4453 & 249 & 4 & $\mathrm{~B}$ & - \\
\hline \multicolumn{11}{|c|}{ MR14-E02 PC11 } \\
\hline Sec. $5,54-56 \mathrm{~cm}$ & 4.48 & 15.1 & 5.92 & 1244 & 8217 & 2654 & 190 & 2 & S & - \\
\hline Sec. 6, 4-6 cm & 4.98 & 14.4 & 5.38 & 1334 & 8027 & 2466 & 220 & 2 & S & - \\
\hline Sec. $6,54-56 \mathrm{~cm}$ & 5.48 & 14.6 & 5.82 & 1659 & 7079 & 2236 & 295 & 2 & S & - \\
\hline Sec. 7, 4-6 cm & 6.00 & 7.7 & 4.84 & 894 & 3519 & 1472 & 156 & 2 & S & - \\
\hline Sec. $7,54-56 \mathrm{~cm}$ & 6.50 & 11.3 & 5.45 & 1447 & 6281 & 2723 & 235 & 2 & B & - \\
\hline Sec. $8,4-6 \mathrm{~cm}$ & 7.00 & 16.4 & 3.88 & 1716 & 13,658 & 5108 & 217 & 3 & B & - \\
\hline Sec. $11,4-6 \mathrm{~cm}$ & 9.98 & 26.9 & 3.49 & 1750 & 25,157 & 4532 & 343 & 1 & $\mathrm{~B}, \mathrm{~S}, \mathrm{SL}$ & Mixed; SL is \\
\hline Sec. $12,4-6 \mathrm{~cm}$ & 10.99 & 24.2 & 4.66 & 2374 & 14,419 & 3688 & 384 & 1 & S, B & $\mathrm{S}$ is dominant. \\
\hline
\end{tabular}

Notes: mbsf: meters below the seafloor. Elemental content data were obtained from Yasukawa et al. [37]. B: botryoidal, S: spherical, and SL: spherical with metallic luster (see text).

\subsection{Geochemical Characteristics of the Classified Fe-Mn Micronodules}

Scatter diagrams of the original elemental contents of the Fe-Mn micronodules provide information on the geochemical features of each cluster (Figure 5). Cluster 4 is characterized by Ni contents above 36,000 ppm. Cluster 5 is discriminated based on Co contents above 2500 ppm. Clusters 2 and 5 have relatively high Fe contents (>4.8 wt.\%), but C2 exhibits lower Co contents than C5. Clusters 1 and 3 generally overlap in the element subspaces. Focusing on the Ni-Cu diagram, $\mathrm{C} 1$ and $\mathrm{C} 3$ can be discriminated by relatively low and high $\mathrm{Cu} / \mathrm{Ni}$ ratios, respectively. Cluster 3 has high $\mathrm{Cu}$ contents ( $\geq 5000 \mathrm{ppm}$ ) compared with the other clusters, although one sample of C4 exhibits a $\mathrm{Cu}$ content of $5900 \mathrm{ppm}$.

The stratigraphic distributions of these features can be visualized by depth profiles of elemental ratios (Figure 6). Clusters 2 and 5 have relatively lower $\mathrm{Mn} / \mathrm{Fe}$ ratios $(\mathrm{Mn} / \mathrm{Fe}<5$; Figure $6 a, h, o$ ) than C1, C3, and C4 (Mn/Fe > 5, except for one C3 sample in PC11; Figure 6o). Cluster 2 is further characterized by the lowest $\mathrm{Co} / \mathrm{Fe}$ ratios $(\mathrm{Co} / \mathrm{Fe}<0.03$; here, the $\mathrm{Co}$ content was converted to wt.\%; Figure $6 \mathrm{~b}, \mathrm{i}, \mathrm{p})$, whereas $\mathrm{C} 5$ exhibits the lowest Ni/Co ratios (Ni/Co < 5; Figure 6d,k). Among the clusters with high $\mathrm{Mn} / \mathrm{Fe}$ ratios, $\mathrm{C} 4$ has the highest $\mathrm{Mn} / \mathrm{Fe}(\mathrm{Mn} / \mathrm{Fe}>10$; Figure 6a,h), highest Ni/Co $(>30$; Figure $6 \mathrm{~d}, \mathrm{k})$, and lowest Cu/Ni $(<0.18$; Figure 6e,l) ratios. Cluster 3 exhibits high $\mathrm{Cu} / \mathrm{Mn}$ ratios (generally $\mathrm{Cu} / \mathrm{Mn}>0.025$; Figure $6 \mathrm{c}, \mathrm{j}, \mathrm{q})$. Although the elemental ratios of $\mathrm{C} 1$ are moderate, it has relatively low $\mathrm{Cu} / \mathrm{Ni}$ ratios $(\mathrm{Cu} / \mathrm{Ni}=0.18-0.26$; Figure $6 \mathrm{e}, \mathrm{l}, \mathrm{s})$. This suggests that $\mathrm{C} 1$ reflects the transition between two distinct clusters (C4 and C5). Although PC11 lacks both C4 and C5, the occurrence of $\mathrm{C} 1$ at or just below the bulk sediment REY peak in PC11 is consistent with 
that in the other cores. Thus, the $\mathrm{C} 1$ micronodules in PC11 correspond to those in PC05 and PC09.

\section{MR14-E02 PC05}
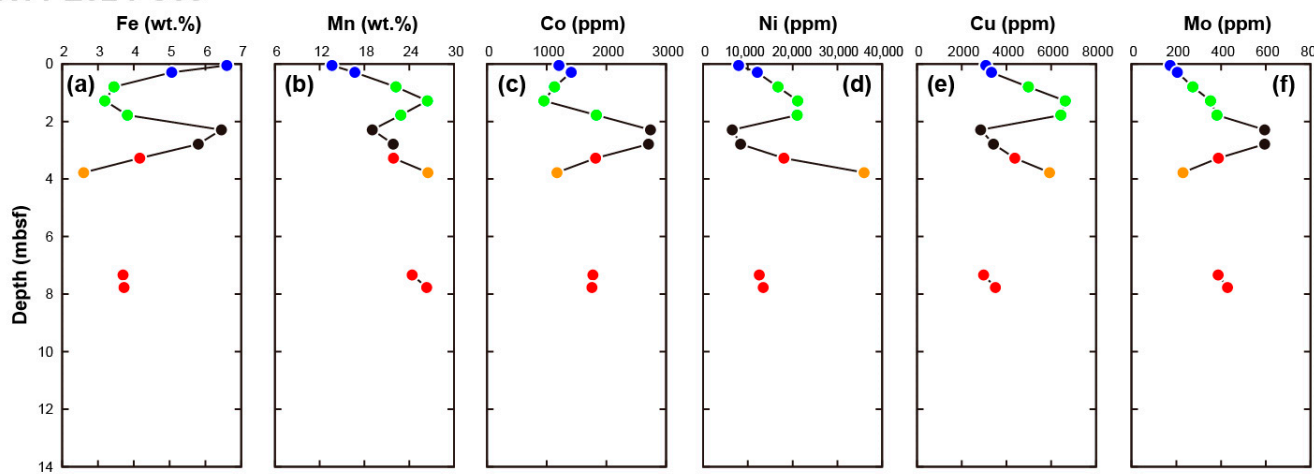

\section{MR14-E02 PC09}
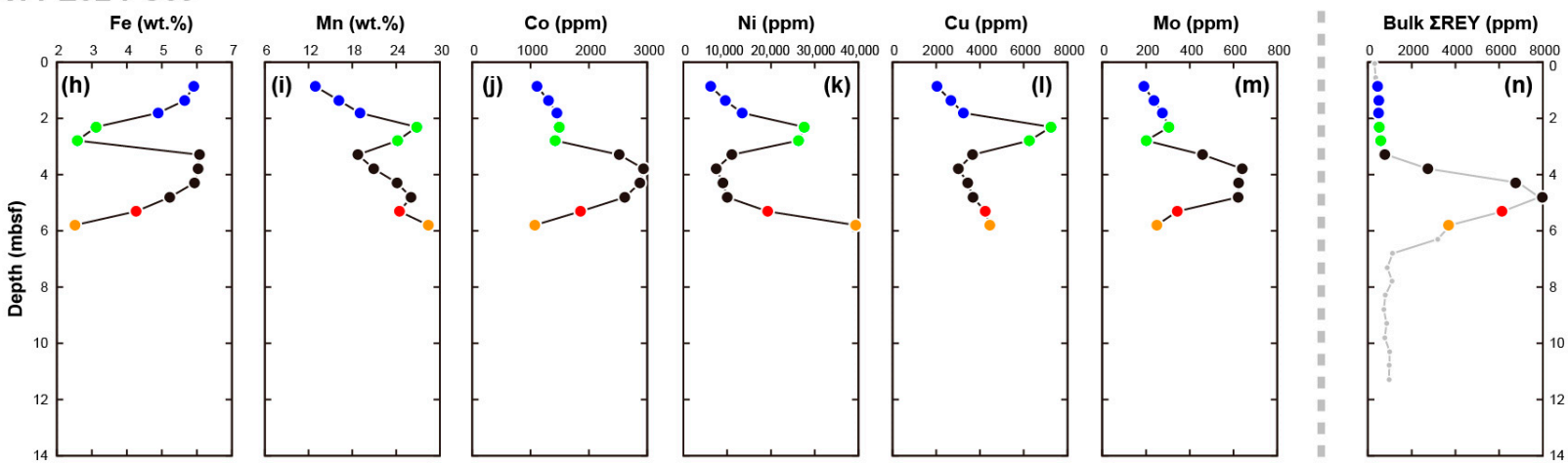

\section{MR14-E02 PC11}
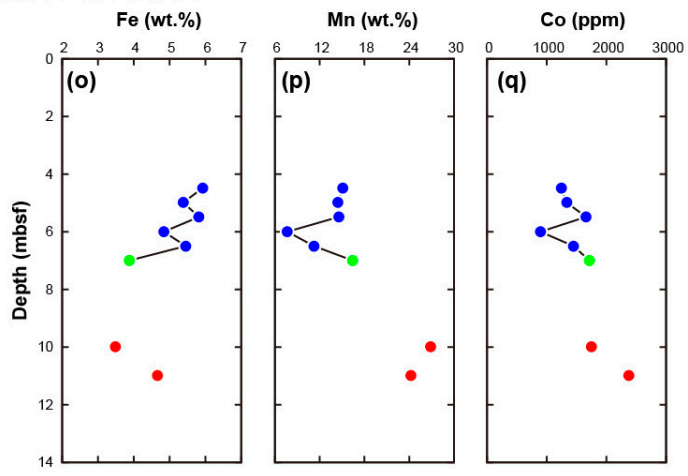

$\mathrm{Ni}(\mathrm{ppm})$

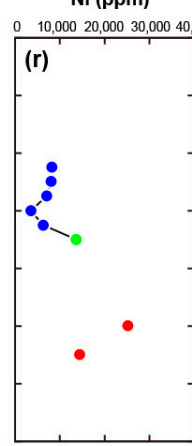

$\mathrm{Cu}(\mathrm{ppm})$

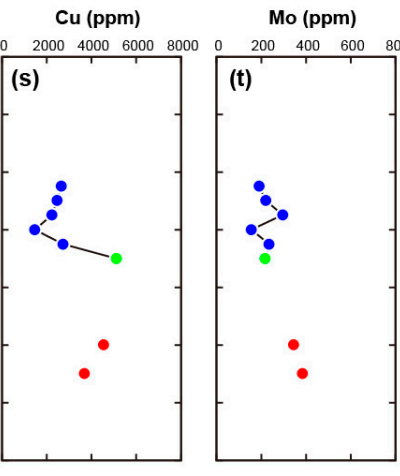

Cluster 5

Figure 4. Downcore variations of the key element contents colored by clusters $(K=5)(\mathbf{a}-\mathbf{f}, \mathbf{h}-\mathbf{m}, \mathbf{o}-\mathbf{t})$. The $\Sigma$ REY contents of the bulk sediments and the clustering based on the Fe-Mn micronodule composition are also shown for comparison ( $\mathbf{g}, \mathbf{n}, \mathbf{u})$.

In the ternary discrimination diagram (Figure 7; [43]), the data of all Fe-Mn micronodules are scattered around the domain of oxic diagenetic origin [37] as well as other Fe-Mn micronodules reported from the North Pacific Ocean [8,9]. Yasukawa et al. [37] pointed out that several samples, which have been classified as $\mathrm{C} 3$ and $\mathrm{C} 4$ in this study, plot closer to the corner of $(\mathrm{Ni}+\mathrm{Cu}) \times 15$ than the oxic diagenetic domain derived from bulk chemical compositions of macroscopic polymetallic nodules (Figure 7). Considering that no clear signature of hydrothermal activity has been identified in the sediments of the study area $[14,35]$, the authors suggested that the samples with extreme compositions (e.g., very high Ni contents) could reflect diagenetic endmembers of Fe-Mn (oxyhydr)oxides, such as 7- $\AA$ and 10 - $\AA$ phyllomanganates $[44,45]$, which are not contaminated by detrital compo- 
nents or other Fe-Mn phases of different origin. Yasukawa et al. [37] also reported that the entire data structure of the micronodules shows a variation parallel to the trend between oxic diagenetic and hydrogenetic domains (Figure 7). This indicates that the source materials and/or environmental factors, such as the redox conditions, involved in the growth of the $\mathrm{Fe}-\mathrm{Mn}$ micronodules might have fluctuated throughout the depositional history of the sediment column. Indeed, C5 micronodules showing a shift toward the hydrogenetic domain from the possible pure diagenetic endmember (i.e., C3 and C4) exhibit high Co contents and low $\mathrm{Ni} / \mathrm{Co}$ ratios compared with the other clusters (Figures 4 and 6). Samples of $\mathrm{C} 1$ are scattered between $\mathrm{C} 5$ and $\mathrm{C} 3 / \mathrm{C} 4$, which is consistent with the transitional feature inferred from the downcore compositional variations.

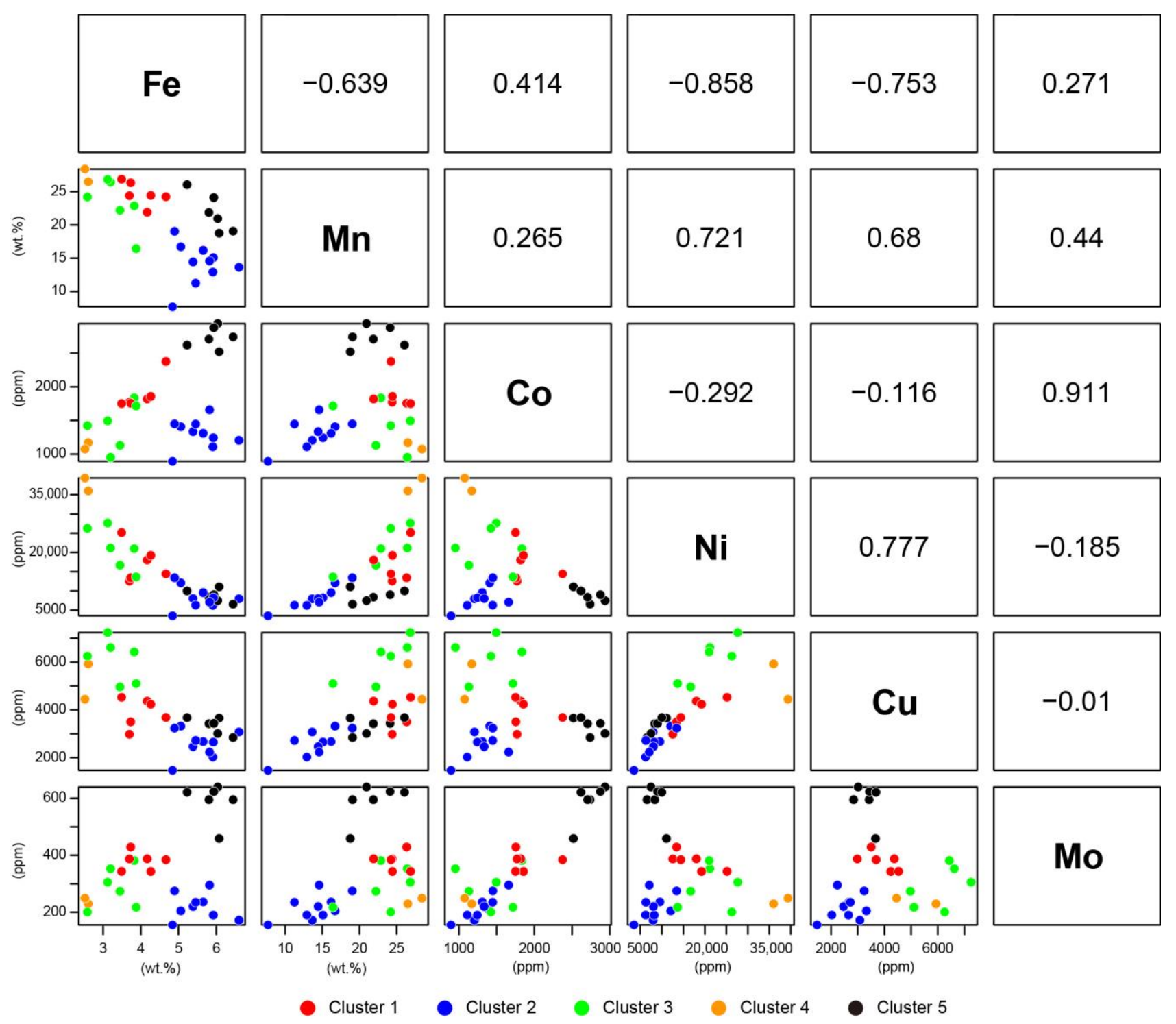

Figure 5. Scatter plot matrix of the Fe-Mn micronodule compositions. The diagonal components represent the variables used in the K-means cluster analysis. The upper panels in the matrix indicate the correlation coefficients for all data. The lower panels show two-dimensional scatter plots for each pair of variables (element contents). The color-coding of the data points is the same as that in Figure 4. 
MR14-E02 PC05
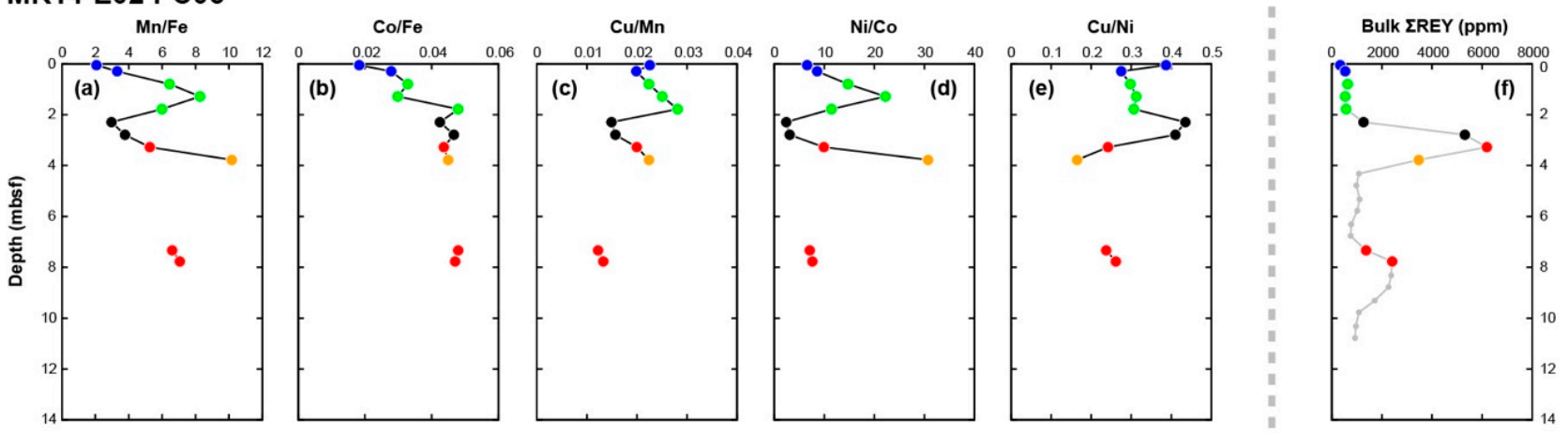

\section{MR14-E02 PC09}
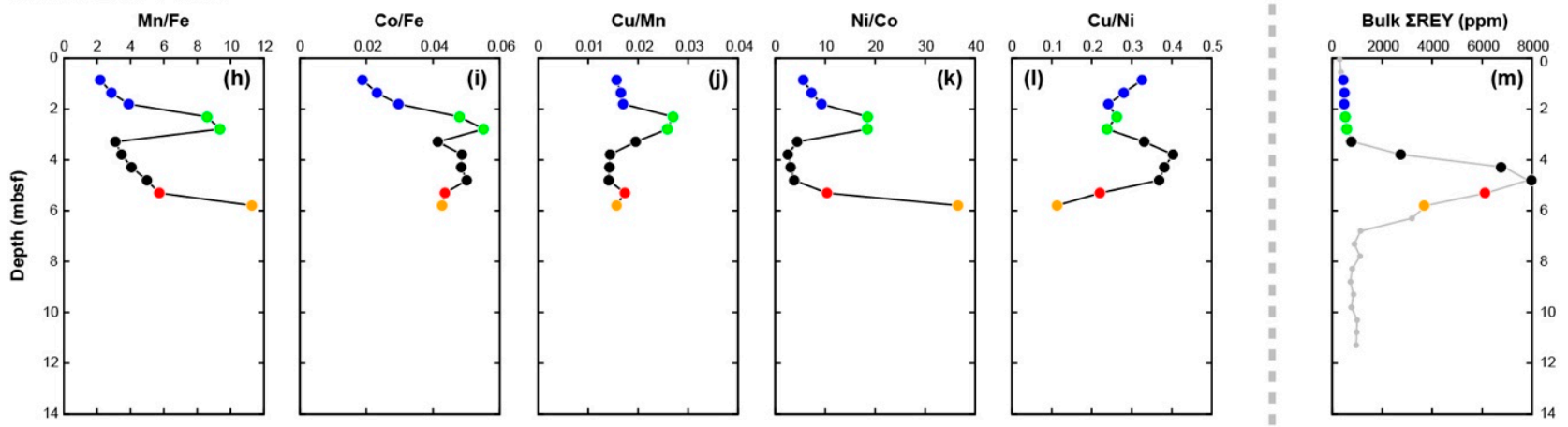

\section{MR14-E02 PC11}
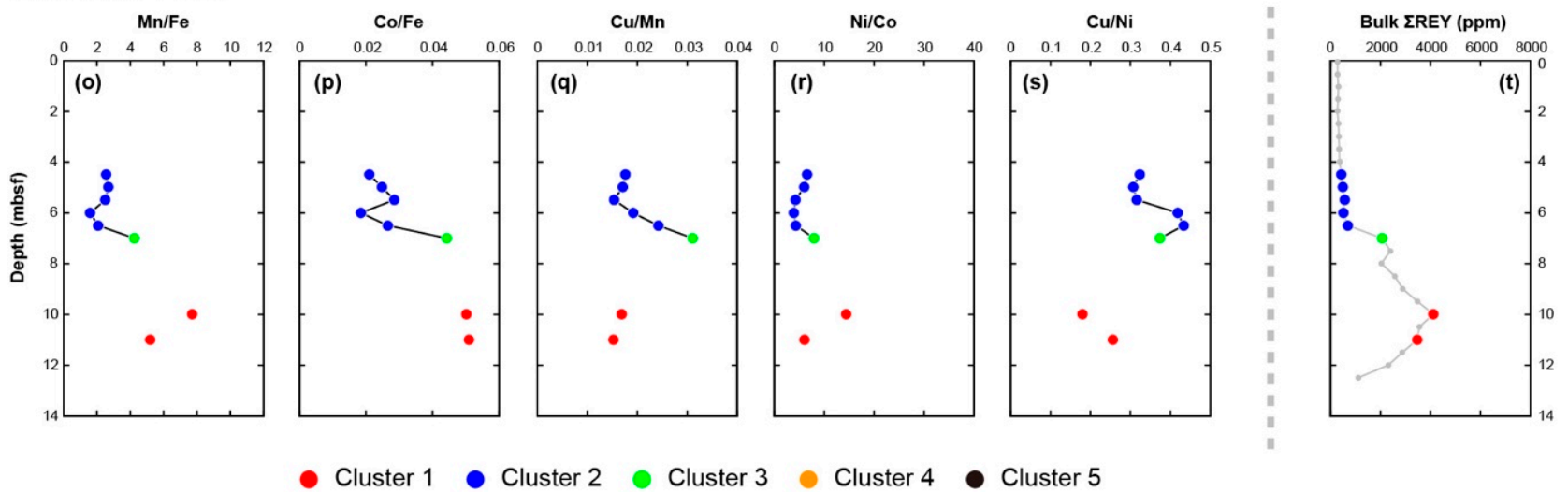

Figure 6. Downcore variations of the key element ratios colored by clusters $(K=5)(\mathbf{a}-\mathbf{f}, \mathbf{h}-\mathbf{m}, \mathbf{o}-\mathbf{t})$. The $\Sigma$ REY contents of the bulk sediments and the clustering are also shown for comparison $(\mathbf{f}, \mathbf{m}, \mathbf{t})$. The color-coding of the data points is the same as that in Figure 4.

Although C2 micronodules broadly overlap with $\mathrm{C} 5$ micronodules in the discrimination diagram (Figure 7), C2 samples do not exhibit an enrichment in Co (Figure 4c,j, q). This suggests that the geochemical signature of $\mathrm{C} 2$ cannot simply be interpreted as hydrogenetic. Considering their relatively low $\mathrm{Co} / \mathrm{Fe}$ ratios $(<0.03$; Figure $6 \mathrm{~b}, \mathrm{i}, \mathrm{p})$ compared with the other clusters, the $\mathrm{C} 2$ micronodules seem to be enriched in Fe that is not associated with $\mathrm{Fe}-\mathrm{Mn}$ (oxyhydr)oxides but possibly related to detrital material such as clay minerals. Given that their $\mathrm{Cu} / \mathrm{Mn}, \mathrm{Ni} / \mathrm{Co}$, and $\mathrm{Cu} / \mathrm{Ni}$ ratios fall in the ranges of those of the other micronodules, the $\mathrm{C} 2$ micronodules reflect a moderately diagenetic origin. 


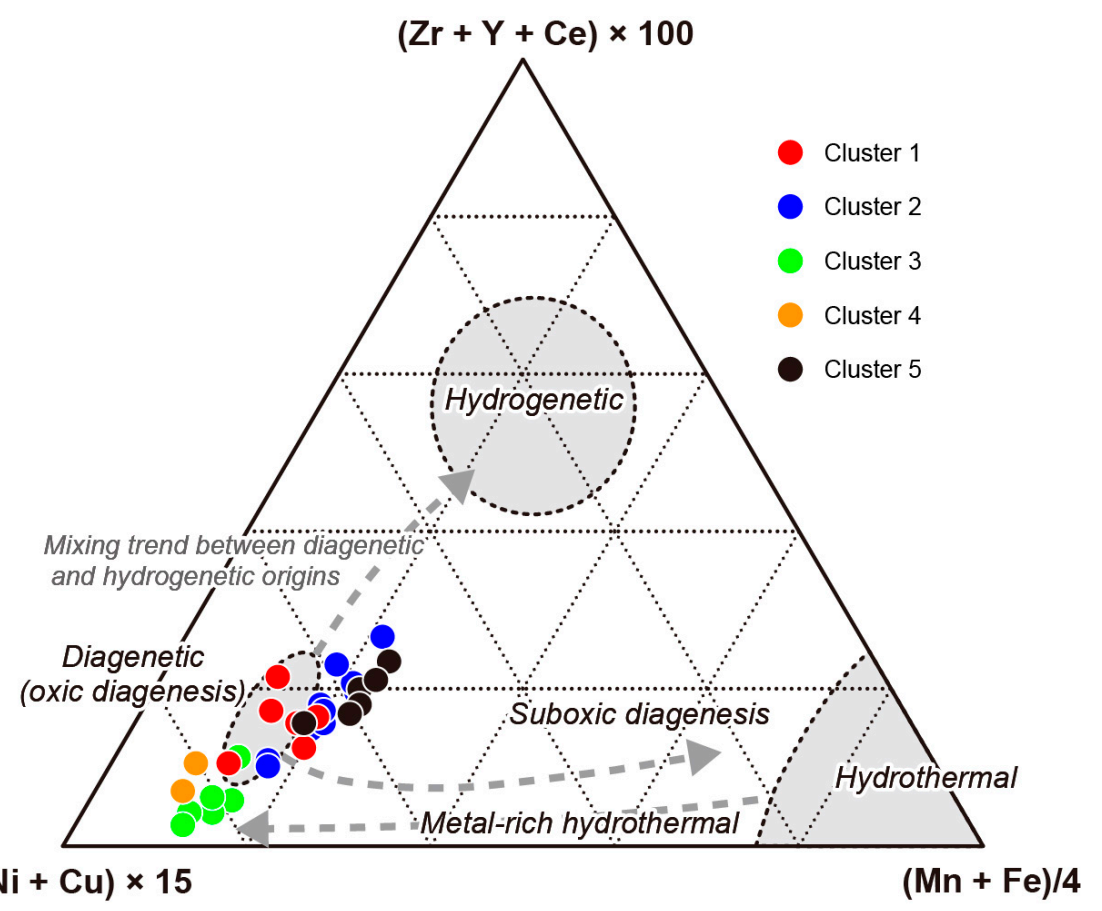

Figure 7. Ternary discrimination diagram for the genetic classification of oceanic Fe-Mn deposits [43]. All data for the Fe-Mn micronodule samples used in this study are plotted. The color-coding of the data points is the same as that in Figure 4.

\subsection{Morphological Characteristics and Surficial Textures of Fe-Mn Micronodules}

The Fe-Mn micronodules investigated in this study exhibit two distinct types of morphological features and visible textures [37] (Figure 8a-d): botryoidal with rough surfaces and spherical with smooth surfaces. In addition, a subtype of spherical micronodules was observed, exhibiting a metallic luster and remarkably smooth surfaces (Figure 8e,f). In this study, we categorized these features of the Fe-Mn micronodules as " $\mathrm{B}$ ", "S", and "SL", corresponding to botryoidal, spherical, and spherical with metallic luster, respectively.

The morphological features and surficial textures of the Fe-Mn micronodules obtained from stereomicroscopic observations are listed in Table 1. Several sample horizons contain a mixture of micronodules of different categories. Although these categories do not correspond to the clustering based on the geochemical features, note that SL-type micronodules overlap with C5 or occur in the upper half of the bulk sediment REY peak. The S-type micronodules occur as C1, C5, and partially as C2 micronodules, sometimes mixed with SL- and B-type nodules. The B-type micronodules generally occur as C3, C4, and partially as $\mathrm{C} 2$ micronodules. The B-type micronodules within the lower part of the bulk REY peak incorporate multiple sedimentary grains of phillipsite and fish debris (Figure 8b), as previously reported by Yasukawa et al. [37].

The results of several previous studies of seafloor Fe-Mn nodules showed that the surficial texture of macro-sized Fe-Mn nodules can be classified into smooth (i.e., "S"-type) and rough (i.e., " $\mathrm{R}$ "-type) types [46-48]. The S-type macronodules are generally spherical and composed of $\delta-\mathrm{MnO}_{2}$. The $\delta-\mathrm{MnO}_{2}$ directly precipitates onto the nodule surface from ambient seawater under oxidizing conditions at a very low sedimentation rate [47,48], resulting in concentric layer structures reflecting the growth history of the nodule. R-type macronodules have irregular shapes, are mainly composed of $10-\AA$ phyllomanganates that show microscopic, dendritic patterns, and are considered to be of diagenetic origin $[46,47]$. The oxidation of organic matter in deep-sea sediments leads to oxygen-poor conditions that can reduce and dissolve Mn-oxides resulting in the release of associated transition metals (e.g., $\mathrm{Ni}$ and $\mathrm{Cu}$; [49]). Because of the concentration gradients in the sediment column, these metals diffuse upwards and are incorporated at the bottom-side of the nodules on the seafloor through the reoxidization by oxic bottom seawater [49]. 

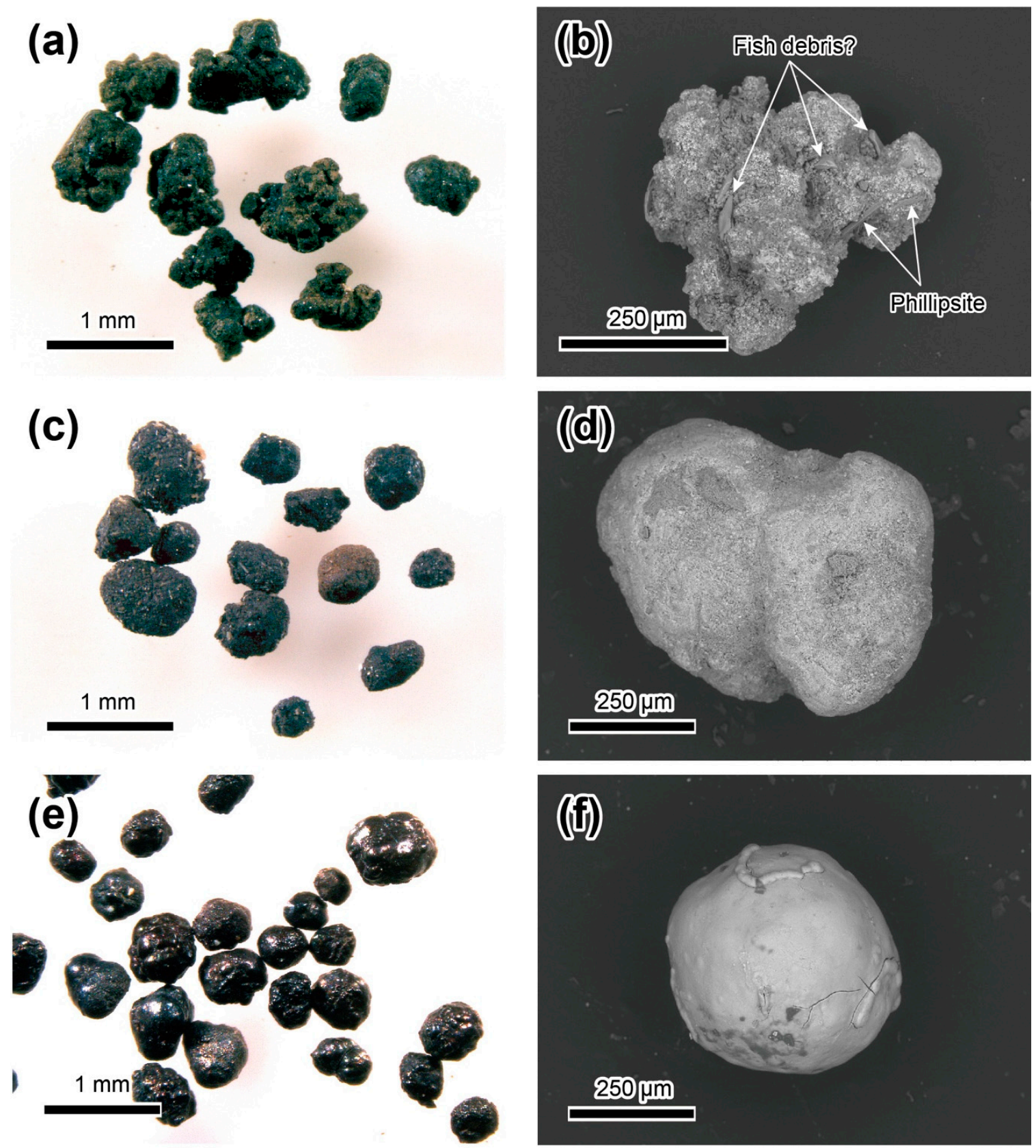

Figure 8. Photomicrographs taken with a stereomicroscope and scanning electron microscope images of representative Fe-Mn micronodule grains. (a) Visual appearance and (b) backscattered electron (BSE) images of B-type micronodules. The samples were taken from (a) MR14-E02 PC05, section 1, 4-6 cm (0.05 m below the seafloor, mbsf; from [37]) and (b) MR14-E02 PC09, section 7, 4-6 cm (5.80 mbsf). (c) Visual appearance and (d) BSE images of S-type micronodules. The samples were taken from (c) MR14-E02 PC09, section 4, 54-56 cm (3.29 mbsf; from [37]) and (d) MR14-E02 PC09, section 2, 54-56 cm (1.36 mbsf). (e) Visual appearance and (f) BSE images of SL-type micronodules. The samples were taken from (e) MR14-E02 PC09, section 5, 54-56 cm (4.29 mbsf) and (f) MR14-E02 PC09, section 6, 4-6 cm (4.81 mbsf).

Although the diameters of the micronodules in the sediments are generally two orders of magnitude smaller than those of the seafloor macro-sized nodules and their genetic relationship remains uncertain, the textures and geochemical features of the micro- and macronodules are similar. The S-type macronodules have high Co contents due to the oxidation of $\mathrm{Co}^{2+}$ to $\mathrm{Co}^{3+}$ in hydrogenetic $\delta-\mathrm{MnO}_{2}$ as well as low $\mathrm{Ni}$ and $\mathrm{Cu}$ contents and low $\mathrm{Mn} / \mathrm{Fe}$ ratios [47-49]. Such features were reported for hydrogenetic $\mathrm{Fe}-\mathrm{Mn}$ deposits, including S-type macronodules and Fe-Mn crusts, close to the study area [50-52]. Our 
S- and SL-type micronodules, especially those classified as C5, exhibit features of S-type macronodules such as high Co contents ( $>2500$ ppm; Figures 4 and 5) and low Ni/Co ratios $(<5$; Figure 6). Although our results suggest that all our samples are of diagenetic origin (Figure 7), these features support our interpretation that the C5 micronodules might have been formed under relatively oxic conditions compared with the other micronodules analyzed in this study. Yasukawa et al. [37] reported that the S-type micronodules (classified as C5 in this study) have finely layered, concentric inner structures similar to S-type macronodules, which could reflect repetitive changes in the physicochemical conditions and/or constituent materials during the growth of the micronodules.

On the other hand, R-type macronodules are characterized by high $\mathrm{Ni}$ and $\mathrm{Cu}$ contents and high $\mathrm{Mn} / \mathrm{Fe}$ ratios, reflecting the effective adsorption or incorporation of $\mathrm{Ni}^{2+}$ and $\mathrm{Cu}^{2+}$ into $\mathrm{Mn}$ mineral layers [44,45,49], and relative depletion of Co. Our B-type micronodules classified as $\mathrm{C} 3$ and $\mathrm{C} 4$ show very high $\mathrm{Cu}$ (up to $7200 \mathrm{ppm}$ ) and $\mathrm{Ni}$ (up to $39,000 \mathrm{ppm}$ ) contents and relatively high $\mathrm{Mn} / \mathrm{Fe}$ ratios ( $>5$; Figures 4 and 6 ). Therefore, compared with the S- and SL-type micronodules, these B-type micronodules might reflect a relatively stronger diagenesis during their formation and could be comparable to that of R-type macronodules.

\subsection{Changes in the Sedimentary Environment during and after the Formation of Extremely REY-Rich Mud}

Based on the combination of all results, we discuss the possible history of sedimentary environmental changes since the formation of the 1st REY peak in the bulk sediment. Figure 9 summarizes the stratigraphic correlation of the geochemical clusters and morphological/textural categories of the Fe-Mn micronodules. The C3 and C4 micronodules reflect an almost pure diagenetic origin, whereas $\mathrm{C} 5$ micronodules are likely to be of relatively hydrogenetic origin. The $\mathrm{C} 2$ micronodules are of moderately diagenetic origin and have relatively low Co contents. The $\mathrm{C} 1$ micronodules exhibit transitional features between C3/C4 and C5. The sequence of clusters and morphological/textural types correlate well among the cores. Because these cores are several tens to $>100 \mathrm{~km}$ apart from each other (Figure 1), this good correlation validates the following discussion of the formation of the extremely REY-rich mud, at least on a regional scale, including a promising area with high REY resource potential in the south of Minamitorishima Island [12,13,35,53].

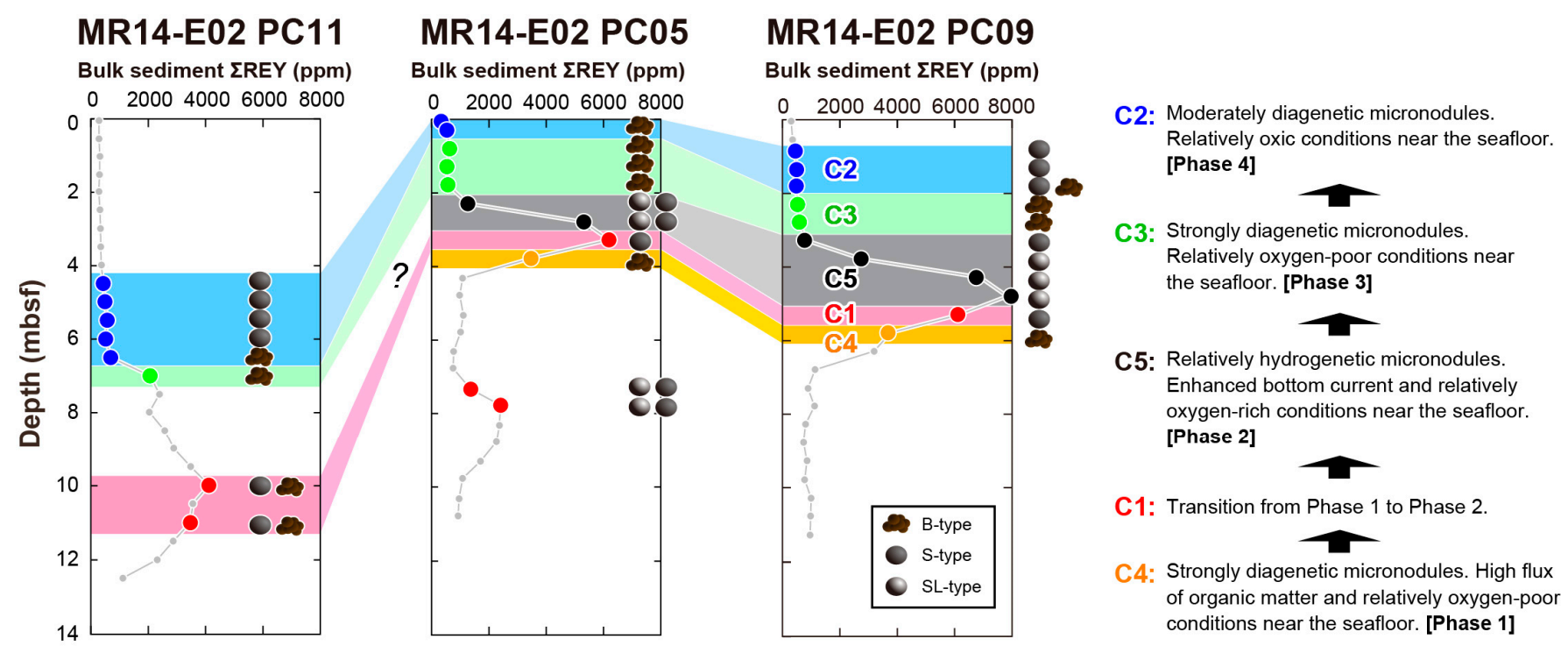

Figure 9. Summarized stratigraphic correlation of the clustering $(K=5)$ and surficial textures of the Fe-Mn micronodules together with the environmental conditions inferred for the sedimentation layers characterized by each cluster.

In the lower part of the 1st REY peak of the bulk sediment, C4 micronodules with a B-type texture were observed. Their very high $\mathrm{Ni}$ contents and irregular shapes suggest 
a strong diagenesis. Because diagenetic micronodules can form both on the seafloor and within the sediment column, it is difficult to determine the exact time of formation. However, because $\mathrm{C} 1$ micronodules with moderately diagenetic origin occur in the deeper part of PC05 (Figures 7 and 9), the strong diagenetic feature of the C4 micronodules is likely due to the environmental conditions in which they formed instead of the depth at which they are buried. Given that strongly diagenetic features are attributable to relatively oxygen-poor conditions (but remain more oxic than suboxic conditions with an oxygen concentration below $5 \mu \mathrm{M}$; [54]), the onset of the 1st REY peak could have accompanied an increase in the organic matter supply and consumption of dissolved oxygen by the oxic degradation of organic matter near the sediment-water interface. In addition, the very high $\mathrm{Ni}$ contents and low $\mathrm{Cu} / \mathrm{Ni}$ ratios of the $\mathrm{C} 4$ micronodules might reflect the element behaviors in the ocean. The vertical distributions of $\mathrm{Ni}$ and $\mathrm{Cu}$ in the ocean can be classified as "nutrient type" and "intermediate type between scavenged and nutrient types", respectively [55]. Nutrient-type elements, including $\mathrm{Ni}$, show vertical concentration profiles with low concentrations in surface water due to the biological uptake and higher concentrations at depth due to the degradation of biomaterial and redistribution of the elements in the deep ocean [55]. In contrast, scavenged-type elements show relative enrichment in the surface water and depletion at depth, resulting from the removal of the elements by adsorption onto sinking particulate matter (called "scavenging mechanism"). Although the behavior of dissolved $\mathrm{Cu}$ in the ocean is complex, reflecting the biological cycling, scavenging, and additional release from seafloor sediments [55], an increase in the surface bioproductivity could have led to an increase in the Ni concentration in deep water, resulting in the efficient incorporation of $\mathrm{Ni}$ into $\mathrm{C} 4$ micronodules at the onset of the formation of extremely REY-rich mud. We call this phase characterized by C4 Phase 1 (Figure 9).

Subsequently, at the culmination and in the upper half of the 1st REY peak of the bulk sediment, C5 micronodules with S- and SL-type textures became characteristic components of the sediment. The $\mathrm{C} 5$ micronodules indicate a relatively hydrogenetic origin, suggesting the prolonged exposure to oxic conditions. This is consistent with an enhanced bottom current proposed by Ohta et al. [36], which could be associated with the rise of Antarctic glaciation during the late Eocene event. A coupled ocean-atmosphere model demonstrated that growth of the Antarctic ice sheet could have invigorated Antarctic bottom water formation and reorganized ocean circulation [56]. Indeed, oxygen isotope ratios of benthic foraminifera indicated that a deep-water mass, that likely originated in the Southern Ocean, spread into the North Pacific Ocean in the latest Eocene (ca. 36.5-34 Ma) [57]. The activation of ocean overturning and strengthened bottom current should have supplied oxygen-rich water mass to the study area. Such an enhancement of the bottom current could have also contributed to the bulk REY-enrichment through a physical process. For example, Ohta et al. [34] proposed that a strong bottom current could have hampered the deposition of fine particles with low REY contents (e.g., clay-sized detrital minerals) and facilitated the sorting of relatively coarse and dense grains, represented by fish debris, on the sediment surface. The finely layered inner structures of the $\mathrm{C} 5$ micronodules might reflect short-term changes of the bottom current intensity, for example, those associated with orbital-scale climatic oscillations [58,59]. We call this phase characterized by C5 Phase 2 (Figure 9).

According to Ohta et al. [36], the surface bioproductivity could have been stimulated by the upwelling of deep ocean nutrients induced by enhanced bottom currents that collided with large seamounts, which caused proliferation of pelagic fish and increased deposition of fish debris. If this is the case, the sequence of Phases 1 and 2 appears unusual because the increase in the organic matter deposition seems to have preceded the bottom current enhancement. However, this can be explained by the lack of information on the background conditions before the formation of the REY peak. The increased bioproductivity and, thus, increased deposition of organic matter and fish debris involved in the formation of $\mathrm{C} 4$ micronodules could also be a result of the enhanced bottom current via possible upwelling, as suggested by Ohta et al. [36]. Subsequently, the bottom current could 
have strengthened, resulting in the culmination of fish debris deposition due to both increased fish population of the surface ocean and effective sorting of sedimentary grains on the seafloor. The increased supply of oxygenated bottom water due to the vigorous ocean overturning can explain the relatively oxygen-rich conditions at the sediment-water interface despite the high surface ocean productivity. The C1 micronodules with S-type texture and intermediate geochemical features between $\mathrm{C} 4$ and $\mathrm{C} 5$ probably reflect the transitional conditions between Phases 1 and 2 (Figure 9).

After the formation of the extremely REY-rich mud, C3 micronodules with B-type texture are common in all three cores (Figure 9). The C3 micronodules show strongly diagenetic features similar to $\mathrm{C} 4$. This implies that the sedimentation environment became relatively oxygen-poor. Considering that the $\mathrm{Ni}$ contents and $\mathrm{Cu} / \mathrm{Ni}$ ratios of the C3 micronodules are intermediate between those of C4 and C5 (Figures 4 and 6), the surface bioproductivity was likely smaller than that in Phase 1. We call this phase Phase 3 (Figure 9).

Subsequently, C2 micronodules with both B- and S-type surficial textures occurred (Table 1 and Figure 9). Stratigraphically, the B-type micronodules in PC09 and PC11 occur immediately after Phase 3; subsequently, S-type micronodules became dominant (Table 1 and Figure 9). This morphological change suggests a further change in the sedimentary environment. Although being of moderately diagenetic origin, the $\mathrm{C} 2$ micronodules show relatively hydrogenetic features compared with the $\mathrm{C} 3$ and $\mathrm{C} 4$ micronodules of almost pure diagenetic origin. Therefore, combined with the S-type texture, the C2 micronodules imply a reoccurring shift towards relatively oxic conditions compared with Phase 3 . However, the much lower Co contents than those of the $\mathrm{C} 5$ micronodules indicate that the exposure time of the $\mathrm{C} 2$ micronodules to bottom seawater might have been shorter than that of the C5 micronodules. We call this phase Phase 4.

Based on the chemostratigraphic correlation of the bulk sediments, Tanaka et al. [35,53] demonstrated that vigorous bottom currents repetitively eroded several sediment layers in the Minamitorishima area. The thin or partially absent sediment layers above the 1st REY peak, which is 34 million years old (i.e., Units I and II; Figure 2), strongly suggest that the bottom currents regained strength after the formation of the extremely REY-rich mud, which is consistent with our interpretation of Phase 4. The absence of S-type C2 micronodules in PC05 might be due to sediment erosion.

\subsection{Implications for the Genesis of Extremely REY-Rich Mud}

The features of the Fe-Mn micronodules support the previously proposed enhancement of bottom currents during the formation of the extremely REY-rich mud $[35,36,53]$. This reinforces the importance of micronodules as effective indicators of the sedimentation environments of oxic pelagic sediments [1-9].

From a perspective of the sedimentation environment, not only the period of the extremely REY-rich mud formation (Phases 1 and 2) but also Phase 4 were likely characterized by enhanced bottom currents. However, no bulk REY peak has been detected above the 1st REY peak in the study area, although sediment erosion has occurred [35,53]. This implies that the enhancement of the bottom current is not sufficient for extreme REY-enrichment, but an increased supply flux of fish debris to the sediment surface is likely an essential factor. The combination of multiple physicochemical processes triggered by a sufficiently energetic bottom water current in the pelagic realm might be responsible for the formation of extremely REY-rich mud, including a cascade of processes, such as the sufficient supply of nutrients to the oligotrophic surface ocean (probably via upwelling; [36]), the biological response to the nutrient supply, an increase in the fish population [36], an increase in the precipitation of abundant fish debris as most important REY host in the sediment $[10,12,34,36]$, and an effective sorting of sedimentary grains that selectively accumulates fish debris on the seafloor and, thus, hampers the dilution of the bulk REY content by other materials [34]. 


\section{Conclusions}

We investigated the geochemical features, morphological features, surficial textures, and stratigraphic distributions of $\mathrm{Fe}-\mathrm{Mn}$ micronodules separated from deep-sea sediments in the western North Pacific Ocean. The main results can be summarized as follows.

1. The studied Fe-Mn micronodule samples can be classified into five clusters based on $\mathrm{KCA}$ of whitened data of the $\mathrm{Fe}, \mathrm{Mn}, \mathrm{Co}, \mathrm{Ni}, \mathrm{Cu}$, and Mo contents. These five clusters are systematically distributed in the sediment column of all studied cores. The order from the bottom to the top is as follows: C4, C1, C5, C3, and C2.

2. Although all $\mathrm{Fe}-\mathrm{Mn}$ micronodules investigated in this study are generally of diagenetic origin, C5 micronodules show relatively hydrogenetic features, such as high Co contents ( $>2500 \mathrm{ppm})$. In contrast, C3 and C4 micronodules with high $\mathrm{Cu}(\geq 5000$ ppm) and very high $\mathrm{Ni}(>36,000 \mathrm{ppm})$ contents seem to be almost pure diagenetic endmembers of Fe-Mn (oxyhydr)oxides. The $\mathrm{C} 1$ micronodules show transitional features between two distinct clusters ( $\mathrm{C} 4$ and $\mathrm{C} 5$ ). The $\mathrm{C} 2$ micronodules seem to be enriched in Fe associated with detrital material such as clay minerals.

3. The morphological and textural features of the $\mathrm{Fe}-\mathrm{Mn}$ micronodules can be categorized into three types: B-type (botryoidal), S-type (spherical), and SL-type (spherical with metallic luster). The B-type micronodules are mainly classified into strongly diagenetic $\mathrm{C} 3$ and $\mathrm{C} 4$, showing $\mathrm{Cu}$ - and Ni-enrichment with relatively high $\mathrm{Mn} / \mathrm{Fe}$ ratios $(>5)$. The B-type micronodules are likely comparable to rough-type macro-sized Fe-Mn nodules on the seafloor. The S-type micronodules occur as C1, C5, and partially as $\mathrm{C} 2$ micronodules, showing features of relatively oxic conditions compared with C3 and C4. The SL-type micronodules can only be found in C5 samples that occur in the upper half of the extremely REY-rich mud. The SL-type micronodules exhibit geochemical features, such as high Co contents and low Ni/Co ratios $(<5)$, similar to those of smooth-type seafloor macronodules.

4. Based on the stratigraphic changes of the Fe-Mn micronodules, we suggest that the sedimentation environment has changed since the formation of the 1st REY peak of the bulk sediment. At the onset of the 1st REY peak, the organic matter supply and consumption of dissolved oxygen by the oxic degradation of organic matter increased near the sediment-water interface due to the enhanced bottom current that caused the upwelling of deep-sea nutrients and an increased pelagic fish productivity. At the culmination and in the upper half of the 1st REY peak of the bulk sediment, the further activation of ocean overturning and strengthened bottom current supplied oxygen-rich bottom water. After the formation of the extremely REY-rich mud, the sedimentation environment became relatively oxygen-poor. Subsequently, the sedimentation environment shifted toward relatively oxic conditions.

5. The absence of a bulk REY peak above the 1st REY peak implies that the enhancement of the bottom current is not sufficient for the formation of the extremely REY-rich mud. A significantly increased supply flux of fish debris to the sediment surface, which is probably induced by the upwelling of deep-sea nutrients to the surface ocean, might be essential for the accumulation of REY in deep-sea sediments.

Supplementary Materials: The following are available online at https:/ / www.mdpi.com/2075-1 63X/11/3/270/s1, Figure S1: Downcore variations of the key element contents colored by clusters $(K=3)$, Figure S2: Scatter plot matrix of the Fe-Mn micronodule compositions colored by clusters $(K=3)$, Figure S3: Downcore variations of the key element contents colored by clusters $(K=4)$, Figure S4: Scatter plot matrix of the Fe-Mn micronodule compositions colored by clusters $(K=4)$, Figure S5: Downcore variations of the key element contents colored by clusters $(K=6)$, Figure S6: Scatter plot matrix of the Fe-Mn micronodule compositions colored by clusters $(K=6)$, Table S1: Result of Principal Component Analysis of bulk chemical composition data of the Fe-Mn micronodules.

Author Contributions: Conceptualization, K.Y., S.K., K.N., and Y.K.; methodology, K.Y. and S.K.; software, K.Y.; investigation, K.Y., S.K., J.O., K.A., E.T., and K.M.; resources, J.O., K.F., and K.N.; data curation, K.Y.; writing — original draft preparation, K.Y.; writing — review and editing, all authors; 
visualization, K.Y., S.K., K.A., J.O., and K.F.; supervision, Y.K.; funding acquisition, K.Y., K.N., and Y.K. All authors have read and agreed to the published version of the manuscript.

Funding: This research was funded by the Japan Society for the Promotion of Science (JSPS) KAKENHI grant numbers 18K14168 and 20H02678 to K.Y., 15H05771 and 20H05658 to Y.K., and 17H01361 to K.N., and by a grant from the Arai Science and Technology Foundation to K.Y.

Institutional Review Board Statement: Not applicable.

Informed Consent Statement: Not applicable.

Data Availability Statement: Not applicable.

Acknowledgments: We are grateful to three anonymous reviewers for their constructive reviews.

Conflicts of Interest: The authors declare no conflict of interest.

\section{References}

1. Kunzendorf, H.; Gwozdz, R.; Glasby, G.P.; Stoffers, P.; Renner, R.M. The distribution of rare earth elements in manganese micronodules and sediments from the equatorial and southwest Pacific. Appl. Geochem. 1989, 4, 183-193. [CrossRef]

2. Sawada, M. Internal texture and chemical composition of manganese micronodules in deep sea sediments from the Central Pacific Basin. Mining Geol. 1988, 38, 27-37, (In Japanese with English abstract). [CrossRef]

3. Sawada, M. Internal texture and chemical composition of manganese micronodules in the zeolitic sediments from the Penrhyn Basin. Mining Geol. 1989, 39, 21-31, (In Japanese with English abstract). [CrossRef]

4. Pattan, J.N. Manganese micronodules: A possible indicator of sedimentary environments. Mar. Geol. 1993, 113, 331-344. [CrossRef]

5. Dubinin, A.V.; Sval'nov, V.N. Geochemistry of the manganese ore process in the ocean: Evidence from rare earth elements. Lithol. Miner. Resour. 2003, 38, 91-100. [CrossRef]

6. Dubinin, A.V.; Sval'nov, V.N.; Berezhnaya, E.D.; Rimskaya-Korsakova, M.N.; Demidova, T.P. Geochemistry of trace and minor elements in sediments and manganese micronodules from the Angola Basin. Lithol. Miner. Resour. 2013, 48, 175-197. [CrossRef]

7. Dubinin, A.V.; Uspenskaya, T.Y.; Rimskaya-Korsakova, M.N.; Demidova, T.P. Rare elements and Nd and Sr isotopic composition in micronodules from the Brazil Basin, Atlantic Ocean. Lithol. Miner. Resour. 2017, 52, 81-101. [CrossRef]

8. Liao, J.; Sun, X.; Wu, Z.; Sa, R.; Guan, Y.; Lu, Y.; Li, D.; Liu, Y.; Deng, Y.; Pan, Y. Fe-Mn (oxyhydr)oxides as an indicator of REY enrichment in deep-sea sediments from the central North Pacific. Ore Geol. Rev. 2019, 112, 103044. [CrossRef]

9. Li, D.; Fu, Y.; Liu, Q.; Reinfelder, J.R.; Hollings, P.; Sun, X.; Tan, C.; Dong, Y.; Ma, W. High-resolution LA-ICP-MS mapping of deep-sea polymetallic micronodules and its implications on element mobility. Gondwana Res. 2020, 81, 461-474. [CrossRef]

10. Iijima, K.; Yasukawa, K.; Fujinaga, K.; Nakamura, K.; Machida, S.; Takaya, Y.; Ohta, J.; Haraguchi, S.; Nishio, Y.; Usui, Y.; et al. Discovery of extremely REY-rich mud in the western North Pacific Ocean. Geochem. J. 2016, 50, 557-573. [CrossRef]

11. Fujinaga, K.; Yasukawa, K.; Nakamura, K.; Machida, S.; Takaya, Y.; Ohta, J.; Araki, S.; Liu, H.; Usami, R.; Maki, R.; et al. Geochemistry of REY-rich mud in the Japanese Exclusive Economic Zone around Minamitorishima Island. Geochem. J. 2016, 50, 575-590. [CrossRef]

12. Takaya, Y.; Yasukawa, K.; Kawasaki, T.; Fujinaga, K.; Ohta, J.; Usui, Y.; Nakamura, K.; Kimura, J.-I.; Chang, Q.; Hamada, M.; et al. The tremendous potential of deep-sea mud as a source of rare-earth elements. Sci. Rep. 2018, 8, 5763. [CrossRef] [PubMed]

13. Yasukawa, K.; Ohta, J.; Mimura, K.; Tanaka, E.; Takaya, Y.; Usui, Y.; Fujinaga, K.; Machida, S.; Nozaki, T.; Iijima, K.; et al. A new and prospective resource for scandium: Evidence from the geochemistry of deep-sea sediment in the western North Pacific Ocean. Ore Geol. Rev. 2018, 102, 260-267. [CrossRef]

14. Yasukawa, K.; Ohta, J.; Miyazaki, T.; Vaglarov, B.S.; Chang, Q.; Ueki, K.; Toyama, C.; Kimura, J.-I.; Tanaka, E.; Nakamura, K.; et al. Statistic and isotopic characterization of deep-sea sediments in the western North Pacific Ocean: Implications for genesis of the sediment extremely enriched in rare-earth elements. Geochem. Geophys. Geosyst. 2019, 20, 3402-3430. [CrossRef]

15. Kyte, F.T.; Leinen, M.; Heath, G.R.; Zhou, L. Cenozoic sedimentation history of the central North Pacific: Inferences from the elemental geochemistry of core LL44-GPC3. Geochim. Cosmochim. Acta 1993, 57, 1719-1740. [CrossRef]

16. Plank, T.; Langmuir, C.H. The chemical composition of subducting sediment and its consequences for the crust and mantle. Chem. Geol. 1998, 145, 325-394. [CrossRef]

17. Kato, Y.; Fujinaga, K.; Nakamura, K.; Yakaya, Y.; Kitamura, K.; Ohta, J.; Toda, R.; Nakashima, T.; Iwamori, H. Deep-sea mud in the Pacific Ocean as a potential resource for rare-earth elements. Nat. Geosci. 2011, 4, 535-539. [CrossRef]

18. Yasukawa, K.; Liu, H.; Fujinaga, K.; Machida, S.; Haraguchi, S.; Ishii, T.; Nakamura, K.; Kato, Y. Geochemistry and mineralogy of REY-rich mud in the eastern Indian Ocean. J. Asian Earth Sci. 2014, 93, 25-36. [CrossRef]

19. Yasukawa, K.; Nakamura, K.; Fujinaga, K.; Machida, S.; Ohta, J.; Takaya, Y.; Kato, Y. Rare-earth, major, and trace element geochemistry of deep-sea sediments in the Indian Ocean: Implications for the potential distribution of REY-rich mud in the Indian Ocean. Geochem. J. 2015, 49, 621-635. [CrossRef]

20. Yasukawa, K.; Nakamura, K.; Fujinaga, K.; Iwamori, H.; Kato, Y. Tracking the spatiotemporal variations of statistically independent components involving enrichment of rare-earth elements in deep-sea sediments. Sci. Rep. 2016, 6, 29603. [CrossRef] 
21. Nakamura, K.; Fujinaga, K.; Yasukawa, K.; Takaya, Y.; Ohta, J.; Machida, S.; Haraguchi, S.; Kato, Y. REY-rich mud: A deep-sea mineral resource for rare earths and yttrium. In Handbook on the Physics and Chemistry of Rare Earths; Elsevier: Amsterdam, The Netherlands, 2015; Volume 46, pp. 79-127. [CrossRef]

22. Zhang, X.; Tao, C.; Shi, X.; Li, H.; Huang, M.; Huang, D. Geochemical characteristics of REY-rich pelagic sediments from the GC02 in central Indian Ocean Basin. J. Rare Earth. 2017, 35, 1047-1058. [CrossRef]

23. Menendez, A.; James, R.H.; Roberts, S.; Peel, K.; Connelly, D. Controls on the distribution of rare earth elements in deep-sea sediments in the North Atlantic Ocean. Ore Geol. Rev. 2017, 87, 100-113. [CrossRef]

24. Sa, R.; Sun, X.; He, G.; Xu, L.; Pan, Q.; Liao, J.; Zhu, K.; Deng, X. Enrichment of rare earth elements in siliceous sediments under slow deposition: A case study of the central North Pacific. Ore Geol. Rev. 2018, 94, 12-23. [CrossRef]

25. Zhou, T.; Shi, X.; Huang, M.; Yu, M.; Bi, D.; Ren, X.; Yang, G.; Zhu, A. The influence of hydrothermal fluids on the REY-rich deep-sea sediments in the Yupanqui Basin, eastern South Pacific Ocean: Constraints from bulk sediment geochemistry and mineralogical characteristics. Minerals 2020, 10, 1141. [CrossRef]

26. Mimura, K.; Nakamura, K.; Yasukawa, K.; Machida, S.; Ohta, J.; Fujinaga, K.; Kato, Y. Significant impacts of pelagic clay on average chemical composition of subducting sediments: New insights from discovery of extremely rare-earth elements and yttrium-rich mud at Ocean Drilling Program Site 1149 in the western North Pacific Ocean. J. Asian Earth Sci. 2019, 186, 104059. [CrossRef]

27. Arrhenius, G.; Bramlette, M.N.; Picciotto, E. Localization of radioactive and stable heavy nuclides in ocean sediments. Nature 1957, 180, 85-86. [CrossRef]

28. Bernat, M. Les isotopes de l'uranium et du thorium et les terres rares dans l'environment marin. Cah. Orstom. Sér. Géol. 1975, 7, 65-83.

29. Elderfield, H.; Pagett, R. Rare earth elements in ichthyoliths: Variations with redox conditions and depositional environment. Sci. Total Environ. 1986, 49, 175-197. [CrossRef]

30. Toyoda, K.; Tokonami, M. Diffusion of rare-earth elements in fish teeth from deep-sea sediments. Nature 1990, 345, 607-609. [CrossRef]

31. Toyoda, K.; Nakamura, Y.; Masuda, A. Rare earth elements of Pacific pelagic sediments. Geochim. Cosmochim. Acta 1990, 54, 1093-1103. [CrossRef]

32. Kashiwabara, T.; Toda, R.; Fujinaga, K.; Honma, T.; Takahashi, Y.; Kato, Y. Determination of host phase of lanthanum in deep-sea REY-rich mud by XAFS and $\mu$-XRF using high-energy synchrotron radiation. Chem. Lett. 2014, 43, 199-200. [CrossRef]

33. Kashiwabara, T.; Toda, R.; Nakamura, K.; Yasukawa, K.; Fujinaga, K.; Kubo, S.; Nozaki, T.; Takahashi, Y.; Suzuki, K.; Kato, Y. Synchrotron X-ray spectroscopic perspective on the formation mechanism of REY-rich muds in the Pacific Ocean. Geochim. Cosmochim. Acta 2018, 240, 274-292. [CrossRef]

34. Ohta, J.; Yasukawa, K.; Machida, S.; Fujinaga, K.; Nakamura, K.; Takaya, Y.; Iijima, K.; Suzuki, K.; Kato, Y. Geological factors responsible for REY-rich mud in the western North Pacific Ocean: Implications from mineralogy and grain size distributions. Geochem. J. 2016, 50, 591-603. [CrossRef]

35. Tanaka, E.; Nakamura, K.; Yasukawa, K.; Mimura, K.; Fujinaga, K.; Iijima, K.; Nozaki, T.; Kato, Y. Chemostratigraphy of deep-sea sediments in the western North Pacific Ocean: Implications for genesis of mud highly enriched in rare-earth elements and yttrium. Ore Geol. Rev. 2020, 119, 103392. [CrossRef]

36. Ohta, J.; Yasukawa, K.; Nozaki, T.; Takaya, Y.; Mimura, K.; Fujinaga, K.; Nakamura, K.; Usui, Y.; Kimura, J.-I.; Chang, Q.; et al. Fish proliferation and rare-earth deposition by topographically induced upwelling at the late Eocene cooling event. Sci. Rep. 2020, 10, 9896. [CrossRef]

37. Yasukawa, K.; Kino, S.; Azami, K.; Tanaka, E.; Mimura, K.; Ohta, J.; Fujinaga, K.; Nakamura, K.; Kato, Y. Geochemical features of Fe-Mn micronodules in deep-sea sediment of the western North Pacific Ocean: Potential for co-product metal extraction from REY-rich mud. Ore Geol. Rev. 2020, 127, 103805. [CrossRef]

38. MacQueen, J. Some methods for classification and analysis of multivariate observations. In Proceedings of the Fifth Berkeley Symposium on Mathematica Statistics and Probability; Le Cam, L.M., Neyman, J., Eds.; University of California Press: Berkeley, CA, USA, 1967; Volume 1, pp. 281-297.

39. Iwamori, H.; Yoshida, K.; Nakamura, H.; Kuwatani, T.; Hamada, M.; Haraguchi, S.; Ueki, K. Classification of geochemical data based on multivariate statistical analyses: Complementary roles of cluster, principal component, and independent component analyses. Geochem. Geophys. Geosyst. 2017, 18, 994-1012. [CrossRef]

40. Iwamori, H.; Nakamura, H.; Chang, Q.; Morikawa, N.; Haraguchi, S. Multivariate statistical analyses of rare earth element compositions of spring waters from the Arima and Kii areas, Southwest Japan. Geochem. J. 2020, 54, 165-182. [CrossRef]

41. Nakamura, H.; Iwamori, H.; Nakagawa, M.; Shibata, T.; Kimura, J.-I.; Miyazaki, T.; Chang, Q.; Vaglarov, B.S.; Takahashi, T.; Hirahara, Y. Geochemical mapping of slab-derived fluid and source mantle along Japan arcs. Gondwana Res. 2019, 70, 36-49. [CrossRef]

42. Hamada, M.; Iwamori, H.; Brandl, P.A.; Ushikubo, T.; Shimizu, K.; Ito, M.; Li, H.; Savov, I.P. Temporal evolution of proto-IzuBonin-Mariana arc volcanism over 10 Myr: Constraints from statistical analysis of melt inclusion compositions. J. Petrol. 2020, 61, egaa022. [CrossRef]

43. Josso, P.; Pelleter, E.; Pourret, O.; Fouquet, Y.; Etoubleau, J.; Cheron, S.; Bollinger, C. A new discrimination scheme for oceanic ferromanganese deposits using high field strength and rare earth elements. Ore Geol. Rev. 2017, 87, 3-15. [CrossRef] 
44. Wegorzewski, A.V.; Kuhn, T. The influence of suboxic diagenesis on the formation of manganese nodules in the Clarion Clipperton nodule belt of the Pacific Ocean. Mar. Geol. 2014, 357, 123-138. [CrossRef]

45. Wegorzewski, A.V.; Grangeon, S.; Webb, S.M.; Heller, C.; Kuhn, T. Mineralogical transformations in polymetallic nodules and the change of $\mathrm{Ni}, \mathrm{Cu}$, and Co crystal-chemistry upon burial in sediments. Geochim. Cosmochim. Acta 2020, 282, 19-37. [CrossRef]

46. Halbach, P.; Scherhag, C.; Hebisch, U.; Marchig, V. Geochemical and mineralogical control of different genetic types of deep-sea nodules from the Pacific Ocean. Miner. Deposita 1981, 16, 59-84. [CrossRef]

47. Usui, A. Regional variation of manganese nodule facies on the Wake-Tahiti transect: Morphological, chemical and mineralogical study. Mar. Geol. 1983, 54, 27-51. [CrossRef]

48. Usui, A.; Nishimura, A.; Tanahashi, M.; Terashima, S. Local variability of manganese nodule facies on small abyssal hills of the Central Pacific Basin. Mar. Geol. 1987, 74, 237-275. [CrossRef]

49. Hein, J.R.; Koschinsky, A.; Kuhn, T. Deep-ocean polymetallic nodules as a resource for critical materials. Nat. Rev. Earth Environ. 2020, 1, 158-169. [CrossRef]

50. Machida, S.; Fujinaga, K.; Ishii, T.; Nakamura, K.; Hirano, N.; Kato, Y. Geology and geochemistry of ferromanganese nodules in the Japanese Exclusive Economic Zone around Minamitorishima Island. Geochem. J. 2016, 50, 539-555. [CrossRef]

51. Nozaki, T.; Tokumaru, A.; Takaya, Y.; Kato, Y.; Suzuki, K.; Urabe, T. Major and trace element compositions and resource potential of ferromanganese crust at Takuyo Daigo Seamount, northwestern Pacific Ocean. Geochem. J. 2016, 50, 527-537. [CrossRef]

52. Azami, K.; Hirano, N.; Machida, S.; Yasukawa, K.; Kato, Y. Rare earth elements and yttrium (REY) variability with water depth in hydrogenetic ferromanganese crusts. Chem. Geol. 2018, 493, 224-233. [CrossRef]

53. Tanaka, E.; Nakamura, K.; Yasukawa, K.; Mimura, K.; Fujinaga, K.; Ohta, J.; Iijima, K.; Nozaki, T.; Machida, S.; Kato, Y. Chemostratigraphic correlations of deep-sea sediments in the western North Pacific Ocean: A new constraint on the distribution of mud highly enriched in rare-earth elements. Minerals 2020, 10, 575. [CrossRef]

54. Hein, J.R.; Koschinsky, A. Deep-ocean ferromanganese crusts and nodules. In Treatise on Geochemistry, 2nd ed.; Holland, H.D., Turekian, K.K., Eds.; Elsevier: Amsterdam, The Netherlands, 2014; Volume 13, pp. 273-291. [CrossRef]

55. Chester, R.; Jickells, T. Marine Geochemistry, 3rd ed.; John Wiley \& Sons, Ltd.: West Sussex, UK, 2012.

56. Goldner, A.; Herold, N.; Huber, M. Antarctic glaciation caused ocean circulation changes at the Eocene-Oligocene transition. Nature 2014, 511, 574-577. [CrossRef] [PubMed]

57. Borrelli, C.; Katz, M.E. Dynamic deep-water circulation in the northwestern Pacific during the Eocene: Evidence from Ocean Drilling Program Site 884 benthic foraminiferal stable isotopes $\left(\delta^{18} \mathrm{O}\right.$ and $\left.\delta^{13} \mathrm{C}\right)$. Geosphere 2015, 11, 1204-1225. [CrossRef]

58. Hein, J.R.; Bohrson, W.A.; Schulz, M.S.; Noble, M.; Clague, D.A. Variations in the fine-scale composition of a central Pacific ferromanganese crust: Paleoceanographic implications. Paleoceanography 1992, 7, 63-77. [CrossRef]

59. Han, X.; Jin, X.; Yang, S.; Fietzke, J.; Eisenhauer, A. Rhythmic growth of Pacific ferromanganese nodules and their Milankovitch climatic origin. Earth Planet. Sci. Lett. 2003, 211, 143-157. [CrossRef] 